\title{
Oxidative DNA double strand breaks and autophagy in the antitumor effect of sterically hindered platinum(II) complexes in NSCLCs
}

\author{
Feihong Chen ${ }^{1}$, Xinyi Wang ${ }^{1}$, Xiufeng Jin ${ }^{1}$, Jian Zhao ${ }^{1}$, Shaohua Gou ${ }^{1}$ \\ ${ }^{1}$ Pharmaceutical Research Center and School of Chemistry and Chemical Engineering, Jiangsu Province Hi-Tech Key \\ Laboratory for Biomedical Research, Southeast University, Nanjing 211189, China
}

Correspondence to: Shaohua Gou, email: sgou@seu.edu.cn

Keywords: platinum(II) complexes, $N^{1}, N^{2}$-diisobutyl moiety, ROS, double strand breaks, MDC1/aprataxin

Received: December 20, $2016 \quad$ Accepted: February 23, $2017 \quad$ Published: March 06, 2017

Copyright: Chen et al. This is an open-access article distributed under the terms of the Creative Commons Attribution License (CC-BY), which permits unrestricted use, distribution, and reproduction in any medium, provided the original author and source are credited.

\section{ABSTRACT}

A series of novel platinum(II) complexes with $(1 \mathrm{R}, \mathbf{2 R})-\mathrm{N}^{1}, \mathrm{~N}^{2}$-diisobutyl-1,2diaminocyclohexane as a carrier ligand, while $\mathbf{N}^{1}, \mathbf{N}^{2}$-diisobutyl moiety serving as steric hindrance were designed, synthesized and characterized. The in vitro biological assays demonstrated that complex 3 had increased cytotoxicity against lung cancer cells, especially non-small-cell lung cancer (NSCLC) compared to its mono-substituted complex $3 a$, indicating that the sterically hindered alkyl moieties have significant influences on its antitumor property. However, the mechanism still remains unclear. The further studies revealed that complex 3 could induce ROS overproduction, severe DNA double strands breaks and inhibit the activation of DNA damage repair proteins within nucleus, leading to cell-cycle arrest and cell death. Moreover, complex 3 could induce autophagy via the accumulation of autophagic vacuoles and alterations of autophagic protein expression. Interestingly, the ROS scavengers, $\mathrm{N}$-acetyl-cysteine (NAC) could reverse complex 3-induced DNA double strands breaks and autophagic responses more significantly compared to complex $3 a$. The results demonstrated that the ROS generation plays an important role in the DNA double strands breaks and autophagic responses in the antitumor effect of complex 3 with $\mathbf{N}^{1}, \mathbf{N}^{2}$-diisobutyl moiety. Our study offered a novel therapeutic strategy and put new insights into the anticancer research of the complexes with $\mathbf{N}^{1}, \mathbf{N}^{2}$-diisobutyl moiety served as steric hindrance.

\section{INTRODUCTION}

In the past three decades, lung cancer was the most frequently diagnosed cancer and the leading cause of cancer death among males as well as females in the developed countries [1]. The mortality rate for lung cancer is 610.2 per 100,000 in China, which accounts for more than one-fifth of all cancer deaths [2]. Non-small-cell lung cancer (NSCLC) occupied approximately $85 \%$ of all these lung malignancies [3]. Standard first-line chemotherapeutic scheme in NSCLC patients was platinum-based combination chemotherapy, which means that platinum compounds were combined with the third generation chemotherapy agents such as gemcitabine, vinorelbine, camptothecin [5-7]. However, side effects of the treatments must be considered carefully. Platinum compounds, for example, are chartered with considerable gastrointestinal toxicities including nausea, vomiting and delayed diarrhea [8]. Moreover, concern with chemotherapy agents is arisen for their association with neurotoxicity, nephrotoxicity and gastrointestinal toxicity [8-11]. Disappointingly, when these targeted agents were combined with chemotherapy agents, neither overall survival nor clinical response rate in phase III clinical trials was significantly developed, while the increased risk of the treatment instead $[8,12,13]$. Thus, it is urgent to find novel drugs with high efficiency rate and low organ toxicity.

Platinum(II)-based drugs, such as cisplatin, carboplatin and oxaliplatin (Scheme 1) are potent cytotoxic agents as the first line treatment for a variety of malignancies despite of severe side effects and innate or acquired resistance. With the success of oxaliplatin, a number of 1,2-DACH derivatives have been designed and tested for their anticancer activities [12-18]. Among 
them, a small number of symmetric $\mathrm{N}^{1}, \mathrm{~N}^{2}$-disubstituted 1,2-DACH derivatives have been used as carrier ligands $[13,14,19,20]$. Our group has previously designed a series of platinum-based complexes bearing N-monosubstituted $1 R, 2 R$-diaminocyclohexane derivatives as carrier ligands which showed optimistic antitumor activity compared with oxaliplatin [21]. Moreover, we synthesized several $\mathrm{Pt}(\mathrm{II})$ complexes of $(1 R, 2 R)-\mathrm{N}^{1}, \mathrm{~N}^{2}$-dibutyl1,2-diaminocyclohexane with two n-butyl branches as steric hindrance, and the in vitro cytotoxicity detections indicated the complexes showed potent antitumor activity [22]. Thus we believed that the increase of sterically hindered effect of the platinum complexes could improve the cytotoxic activity and decrease the side effects, then we intend to introduce two alkyl moieties to the $1 R, 2 R-$ $\mathrm{DACH}$ skeleton to further study the sterically hindered effect of the platinum complexes.

Autophagy is an evolutionarily conserved process for degrading long-lived and misfolded proteins, damaged and dysfunctional organelles, and foreign particles [23]. During autophagy, double-membrane vacuoles, called autophagosomes, are formed in the cytoplasm. Microtubule-associated protein light chain 3 (LC3) is essential for the formation of autophagosomes and is critical for the progression of autophagy. Therefore, LC3 is a consistent marker of autophagy [24]. Cytoplasmic components embedded in autophagosomes are delivered and degraded in an autolysosome structure [25]. Autophagy is critical for the maintenance of homeostasis and in certain diseases, such as viral infections, neurodegeneration, cardiovascular diseases, cancers and aging [26-28].

Oxidative stress resulted from excessive generation of ROS induces multiple biological responses, such as DNA damage inclusive of DNA double-strand breaks (DSBs) and single-strand breaks (SSBs), cell cycle arrest, autophagy and apoptosis. DNA damage response activated ATM, Chk1/2, p53 and subsequently resulted in cell cycle arrest and apoptosis. As key mediators of DSBs and SSBs repair, MDC1/aprataxin and XRCC1 could be activated in nucleus [29]. Moreover, previous studies demonstrated that the proliferation inhibition of cancer cells could be mediated by autophagy via ROS generation. Thus, the level of ROS has been widely elevated by cellular cytotoxic agent that was demonstrated to trigger autophapic cell death. To determine whether Pt(II) complexes of (1R,2R)$\mathrm{N}^{1}, \mathrm{~N}^{2}$-dibutyl-1,2-diaminocyclohexane could trigger ROS-

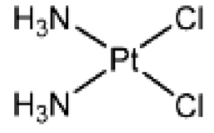

Cisplatin

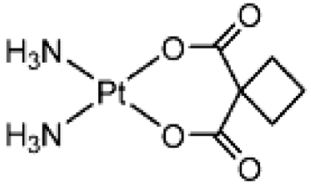

Carboplatin mediated DNA damage and autophagic responses, we detected the level of ROS generation and DNA damage, the autophagic vacuoles and protein expression in vitro and vivo. Recently, the synthesized Pt(II) complexes of $(1 R, 2 R)-\mathrm{N}^{1}, \mathrm{~N}^{2}$-dibutyl-1,2-diaminocyclohexane with two isobutyl branches as steric hindrance have been evaluated for their in vitro cytotoxicities against human tumor cell lines. The flow cytometric detection was carried out to test the apoptotic effect and cell cycle arrest, ROS level of the complexes in the selected cancer cell lines along with the disfunction of mitochondria, while the comet and western blot assays determined the DNA damage level and the autophagic responses. Generally, the study summarizes the influence of the resulting platinum complexes on ROSmeditated DNA damage and autophagy, with the induction of cell apoptosis and death.

\section{RESULTS}

\section{Synthesis and characterization}

The four platinum(II) complexes were prepared following the procedures listed in Scheme 2. Under the protection of nitrogen and dark, an aqueous solution of $\mathrm{K}_{2} \mathrm{PtCl}_{4}$ was added to $\mathrm{L}$ to generate complex 1 . The completion of the reaction took a long time than expected, indicating that alkyl species have caused hindrance for the ligand to bind the metal atom. Further reactions of complex 1 with the corresponding silver dicarboxylate were carried out in water to form $(1 R, 2 \mathrm{R})-\mathrm{N}^{1}, \mathrm{~N}^{2}-$ diisobutyl-1,2-DACH-Pt(II) conjugates (complexes 2-4).

The newly synthesized platinum(II) complexes were characterized by elemental analysis, IR, ${ }^{1} \mathrm{H}$ NMR spectra and electrospray ionization mass (ESI-MS) spectroscopy. In the infrared spectra, the N-H stretching vibrations of complexes 1-4 were obviously shifted to lower frequencies as compared with the free ligand, due to the coordination of the amino group with $\mathrm{Pt}(\mathrm{II})$ ions. Besides, the $\mathrm{C}=\mathrm{O}$ vibration of complexes 2-4 appeared in the range from 1579 to $1646 \mathrm{~cm}^{-1}$, which were characteristic of coordinated dicarboxylates, while the C-O feature appeared in the range of $1350-1396 \mathrm{~cm}^{-1}$. All the ${ }^{1} \mathrm{H}$ NMR spectral data are reasonably attributed to the molecular structures of the synthesized compounds. Furthermore, all the platinum(II) complexes showed 100\% of $[\mathrm{M}+\mathrm{Na}]^{+}$or $[\mathrm{M}+\mathrm{Cl}]^{-}$peaks in ESI-MS spectroscopy.

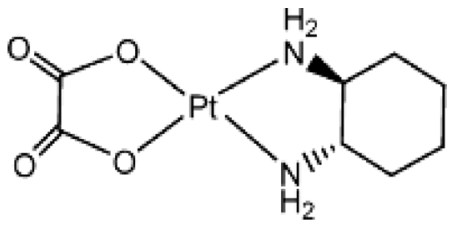

Oxaliplatin

Scheme 1: Structures of cisplatin, carboplatin, oxaliplatin. 


\section{In vitro cytotoxic activity}

The cytotoxicity of the synthesized complexes was evaluated via MTT assays toward HepG2, SGC7901, A549, HCT-116 cancer cell lines and L02 normal liver cell line with oxaliplatin as a positive control. The corresponding $\mathrm{IC}_{50}$ values are presented in Table 1. As shown in Table 1, it is clear to find that complex 1 had considerable cytotoxicity against the tested cell lines, except A549. Complex 2 showed selective activity against certain tested cell lines (A549, HCT-116) while complex 4 has nearly no antitumor activity against all cancer cell lines. Interestingly, complex 3 showed better cytotoxicity activity against all the tested cell lines, especially against A549 compared to oxaliplatin and its monosubstituted complex 3a, [(1R,2R)- $\mathrm{N}^{1}-(2$-methylpropyl)1,2-cyclohexanediamine-N,N'](malonato-O,O') (Table 2 ), while complex 3 showed lower cytotoxicity against L02 cell line with the $\mathrm{IC}_{50}$ of $82.57 \pm 3.95 \mu \mathrm{M}$ compared with the positive control oxaliplatin of $42.9 \pm 3.54 \mu \mathrm{M}$. By comparing the cytotoxicity of complexes 1-4 to oxaliplatin, we can conclude that the existence of alkyl moieties, on each amino group of 1,2-DACH has a significant influence on the antitumor property of complex 3 up to 7.94-folds and 5.37-folds increased in contrast to oxaliplatin and complex $3 \mathrm{a}$. The results reveal that the steric hindrance plays a significant role in the cytotoxicity of complex 3 .

\section{Complex 3 improved the cellular uptake of Pt in NSCLCs}

The better cytotoxicity of complex 3 owing to the DNA platination could be detected in the presence of $\mathrm{EtBr}$ as a probe via fluorescent measurements, because their DNA platination could prevent the formation of EtBr-DNA complex, resulting in its stoichiometric loss of fluorescence. It was observed in Figure 1A that complex 3 could cause more fluorescent intensity change compared to complex $3 \mathrm{a}$, while oxaliplatin could definitely lead to a little loss of fluorescent intensity under the same condition. The above results indicated that complex 3 can induce DNA platination to exert its cytotoxic effect.

One of the main factors to determine the mechanism of cytotoxic activity of a metal-based drug is its ability to cross the cell membrane and to accumulate in cancer cells. Therefore, with the aim of correlating cellular accumulation, we investigated the cellular uptake of the platinum complexes in A549, NCI-H1299 cancer cells and L02 normal cell. After $8 \mathrm{~h}$ treatment of oxaliplatin, complex 3 and complex $3 \mathrm{a}$ of $10 \mu \mathrm{M}$, the platinum contents in these cancer cells and normal cell were analyzed via ICP technique. As Figure 1B shown, the Pt accumulations of complex 3 in A549 and NCI-H1299 cancer cells were increased compared to complex $3 \mathrm{a}$ (2.4 and 2.0 times, respectively), and higher than that of oxaliplatin (2.0 and 1.9 times, respectively), while there is 1.1 -folds lower in HUVEC normal cells compared to oxaliplatin. Moreover, the amount of $\mathrm{Pt}$ in the different subcellular compartments of cancer cells was quantified to fetch a more detailed picture of Pt-based complexes intracellular localization (Figure 1C). As expected for oxaliplatin, which is known to induce cell death by forming adducts on nucleus DNA, $63 \%$ of the total intracellular Pt was located in the nucleus of A549 cancer cells, while $57 \%$ in NCI-H1299 cancer cells. In contrast, the ratio was $79 \%$ and $72 \%$ for complex 3 in A549 and NCI-H1299 cells, respectively, while there is 1.2-folds higher in both cancer cells compared to its mono-substituted complex $3 \mathrm{a}$. Thus, these results indicated that the increased cellular uptake of complex 3
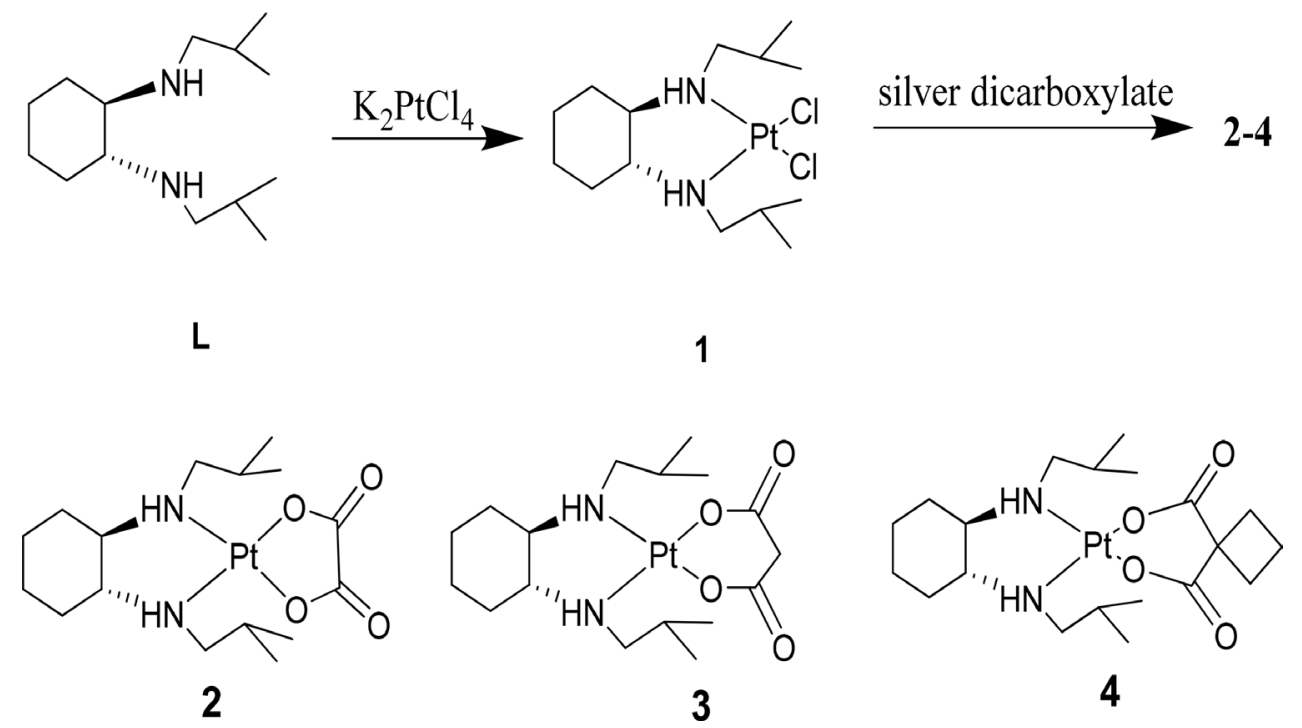

Scheme 2: Synthetic pathway to target complexes 2-4. 
Table 1: In vitro cytotoxicity of complexes 1-4 and oxaliplatin

\begin{tabular}{|c|c|c|c|c|c|c|}
\hline \multirow[t]{2}{*}{ Complexes } & \multicolumn{6}{|c|}{$\mathrm{IC}_{50}(\boldsymbol{\mu M})^{\mathrm{a}}$} \\
\hline & HepG2 & SGC-7901 & HCT-116 & A549 & NCI-H1299 & L02 \\
\hline Complex 1 & $34.07 \pm 2.55$ & $44.60 \pm 3.24$ & $70.55 \pm 5.56$ & $>100$ & $>100$ & $147.75 \pm 10.6$ \\
\hline Complex 2 & $>100$ & $>100$ & $37.03 \pm 2.76$ & $28.38 \pm 1.45$ & $>100$ & $>100$ \\
\hline Complex 3 & $52.90 \pm 4.37$ & $38.63 \pm 2.49$ & $38.60 \pm 2.67$ & $14.17 \pm 1.22$ & $20.92 \pm 1.36$ & $82.57 \pm 3.95$ \\
\hline Complex 4 & $>100$ & $>100$ & $>100$ & $>100$ & $>100$ & $>100$ \\
\hline Oxaliplatin & $16.6 \pm 0.56$ & $24.2 \pm 0.35$ & $19.1 \pm 1.89$ & $112.5 \pm 11.3$ & $62.4 \pm 2.35$ & $42.9 \pm 3.54$ \\
\hline
\end{tabular}

${ }^{a}$ Mean value \pm standard deviation from three independent experiments; $\mathrm{IC}_{50}$ defined after $48 \mathrm{~h}$ drug exposure.

Table 2: In vitro cytotoxicity of complex 3 and $3 a$ exposed for $48 \mathrm{~h}$

\begin{tabular}{|l|l|l|l|l|l|}
\hline \multirow{2}{*}{ Complexes } & \multicolumn{4}{c}{$\mathrm{IC}_{\mathbf{5 0}}(\boldsymbol{\mu M})$} \\
\cline { 2 - 7 } \multicolumn{1}{c}{ HepG2 } & \multicolumn{1}{c}{ HCF-7 } & \multicolumn{1}{c}{ H549 } & \multicolumn{1}{c}{ NCI-H1299 } \\
\hline 3 & $52.90 \pm 4.37$ & $32.50 \pm 2.9$ & $38.60 \pm 2.67$ & $14.17 \pm 1.22$ & $20.92 \pm 1.36$ \\
\hline $3 \mathrm{a}^{\mathrm{a}}$ & $>100$ & $>100$ & $65.8 \pm 4.95$ & $77.5 \pm 5.04$ & $94.85 \pm 6.74$ \\
\hline
\end{tabular}

$\mathrm{a}$<smiles>CC(C)CN[Pb]1(NC2CCCCC2)OC(=O)CC(=O)O1</smiles>

compared to its mono-substituted complex $3 \mathrm{a}$ attributed to its unique structure of steric hindrance.

\section{Complex 3 inhibited cells viability and induced cell apoptosis in NSCLC cells}

The effects of complex 3 on the viability of NSCLC cancer cells including A549 and NCI-H1299 were detected respectively via MTT assays at time points of 12, 24, 48 and $72 \mathrm{~h}$ (Figure 2A). The results shown that complex 3 could inhibit the viability of the NSCLC cells. A549 and NCI-H1299 cells treated by complex 3 for $24 \mathrm{~h}$ within the concentrations ranging from 2 to $128 \mu \mathrm{M}$ exhibit significant inhibition of cell viability in a concentration-dependent manner. The $\mathrm{IC}_{50}$ values for A549 and NCI-H1299 cells exposed for $24 \mathrm{~h}$ were 6.55 and $7.42 \mu \mathrm{M}$ respectively, indicating that complex 3 could effectively suppressed the viability of these NSCLC cells for $24 \mathrm{~h}$. Hence, the further studies were carried out on cancer cells exposed for 48 and $72 \mathrm{~h}$.

Apoptosis is a crucial programmed death form of aging or damaged cells [30]. To confirm whether the cell viability-inhibition effects of complex 3 were resulted from apoptosis induction, the Annexin V/PI double staining assay was used on A549 and NCI-H1299 cells treated with oxaliplatin, complex $3 \mathrm{a}$ and complex 3 for $24 \mathrm{~h}$. The results in Figure 2B implied that early and median apoptotic cells of A549 and NCI-H1299 cells were increased to $29.50 \%, 12.37 \%, 0.94 \%$ and $10.27 \%$,

$4.58 \%, 9.77 \%$ following treatment of oxaliplatin, complex $3 \mathrm{a}$ and complex 3 respectively with $50 \mu \mathrm{M}$ for $24 \mathrm{~h}$, while the late apoptotic cells were increased strikingly to $39.87 \%, 18.95 \%, 4.95 \%$ and $15.98 \%$, $4.12 \%, 27.51 \%$. Thus, the apoptotic rates of A549 and NCI-H1299 cancer cells treated with complex 3a and 3 indicated that the unique structure of the large steric hindrance of complex 3 performed higher apoptotic rates compared to its mono-substituted complex 3a, which was consistent with its cell viability inhibition due to the large steric hindrance of complex 3. The results of microscopic examination and DAPI staining (Figure 2C and 2D) revealed that the occurrence of cell shrinkage, cell rounding, chromatin condensation, and nuclei fragmentation after treatment with complex 3 of $10 \mu \mathrm{M}$. To further explore the impact of complex 3 on long-term clonogenic survival, colony formation assay was performed.

The caspase-3 activity in cancer cells was determined at concentration of $10 \mu \mathrm{M}$ of oxaliplatin, complex $3 \mathrm{a}$ and complex 3 for $24 \mathrm{~h}$. The cells incubated with complex 3 showed a high degree of caspase-3 activity compared to oxaliplatin in A549 and NCI-H1299 cancer cells (Figure 2E). The findings indicated that complex 3 might induce higher level of caspase-dependent apoptosis than oxaliplatin in NSCLC cancer cells. The results shown in Figure $2 \mathrm{~F}$ revealed that complex 3 significantly reduced colony formation compared to its mono-substituted complex 3a in A549 and NCI-H1299 cancer cells, demonstrating 
A

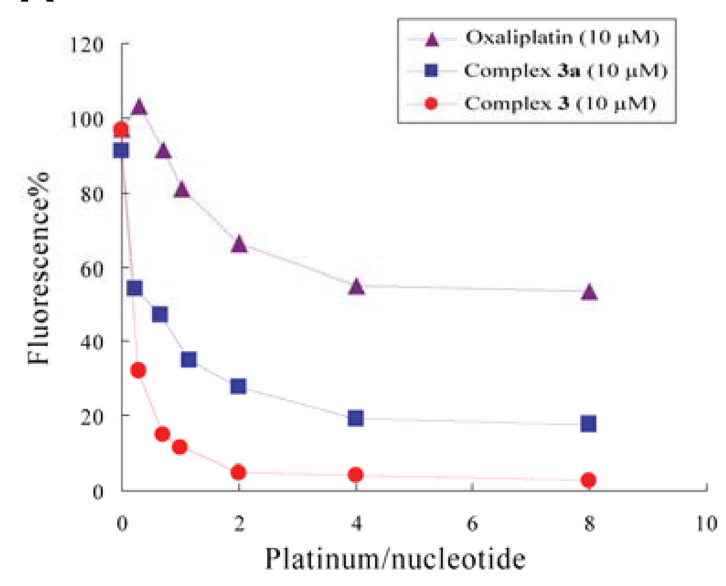

B

\begin{tabular}{lccc} 
Compounds & \multicolumn{3}{c}{ Pt content (ng/10 cells) } \\
\hline Oxaliplatin & $89 \pm 10.7$ & NCI-H1299 & L02 \\
Complex 3 & $179 \pm 20.6$ & $175 \pm 18.5$ & $47 \pm 5.3$ \\
Complex 3a & $75 \pm 6.9$ & $88 \pm 11.7$ & $42 \pm 5.8$
\end{tabular}
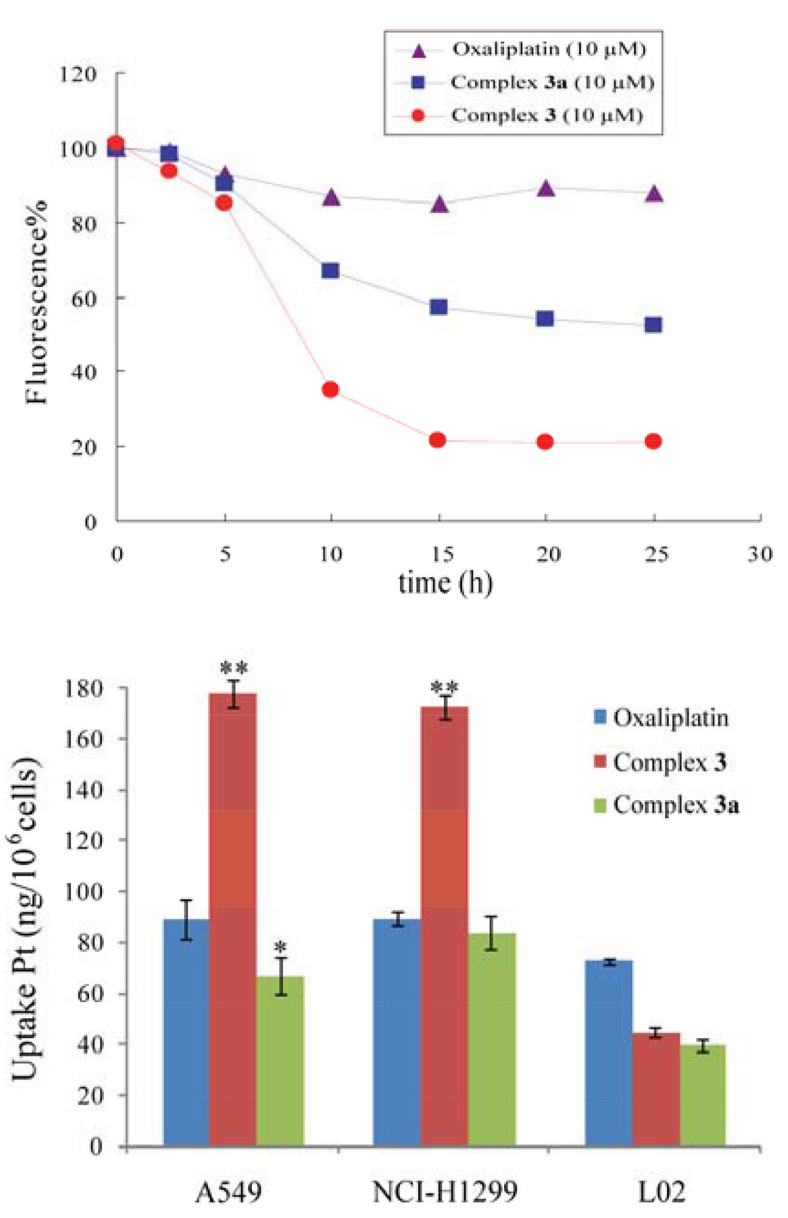

Oxaliplatin

Complex 3
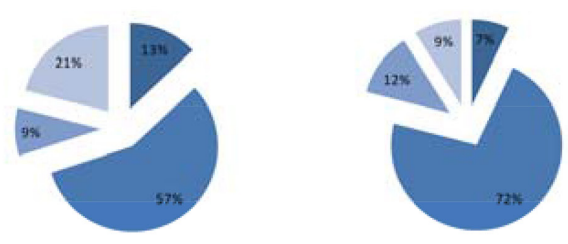

\section{Complex 3a}

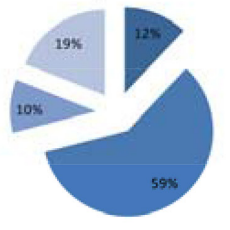

$$
\begin{aligned}
& \text { " residual } \\
& \text { " nucleus } \\
& \text { = mitochondria } \\
& \text { = lysosome }
\end{aligned}
$$

Figure 1: Reactions of complex 3 with DNA by reduction. (A) The different $\mathrm{Pt} /$ nucleotide ratios and time of DNA platination. All the reactions were conducted with $0.01 \mathrm{mg} / \mathrm{mL}$ DNA in $10 \mathrm{mM} \mathrm{NaClO}_{4}$ in $10 \mathrm{mM}$ phosphate buffer $(\mathrm{pH}=7.4)$ at $37^{\circ} \mathrm{C}$ for $24 \mathrm{~h}$ and then add $0.04 \mathrm{mg} / \mathrm{mL} \mathrm{EtBr}$ before the fluorescence measurements with the excitation wavelength of $546 \mathrm{~nm}$ and the emission wavelength of 590 nm. (B) The cellular uptake of oxaliplatin, complex 3, complex in A549, NCI-H1299 and L02 cells. (C) The accumulation of the measured compounds in mitochondria, lysosomes and nucleus of A549 and NCI-H1299 cells. The levels of Pt in cancer cells were detected by ICPMS after $4 \mathrm{~h}$ incubation with the treatments of evaluated complexes at $10 \mu \mathrm{M}$. Results are representative of at least three independent experiments and shown as the mean \pm S.D. ${ }^{*} P<0.05$, ${ }^{* *} P<0.01$ compared with oxaliplatin-treated groups. 

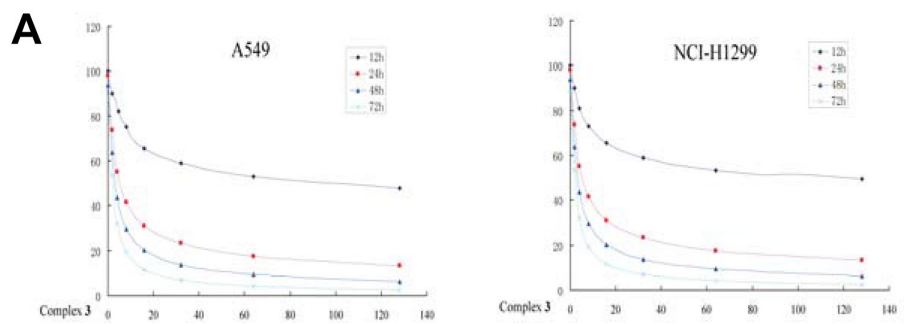

B
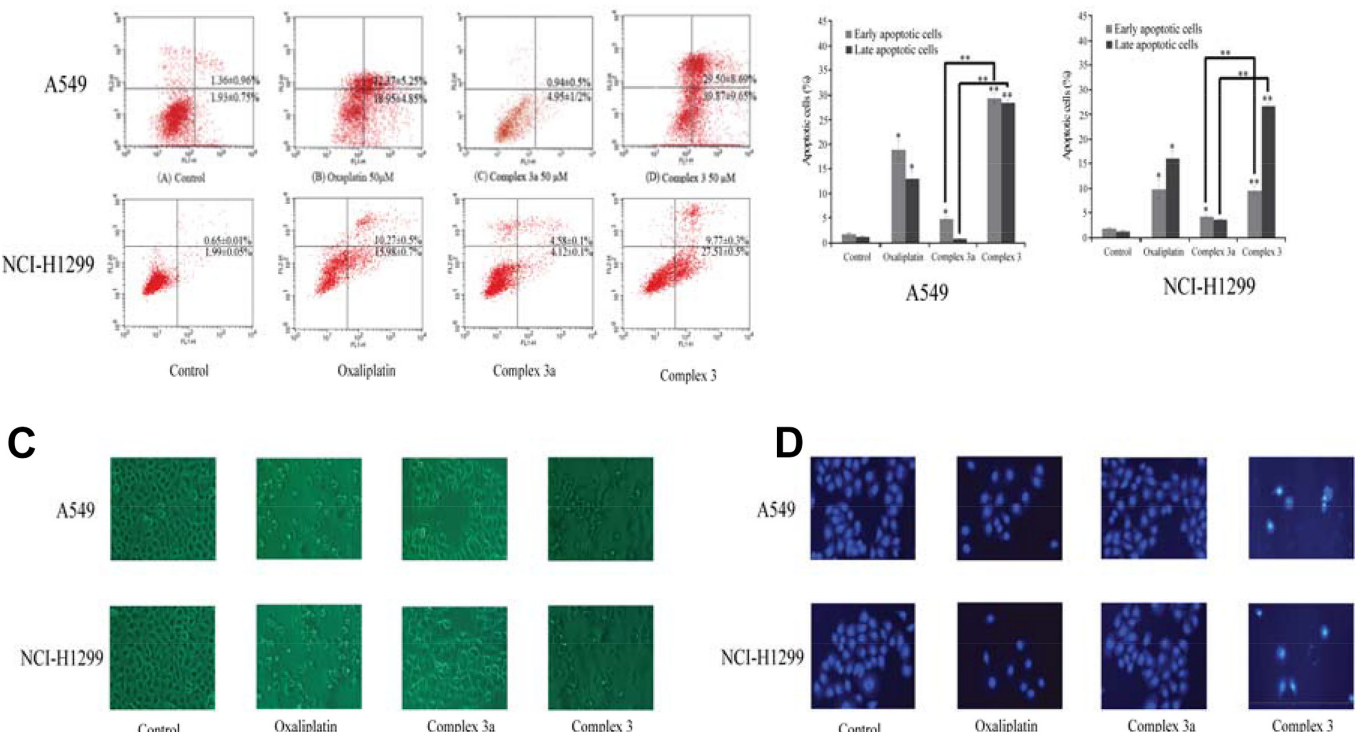

E
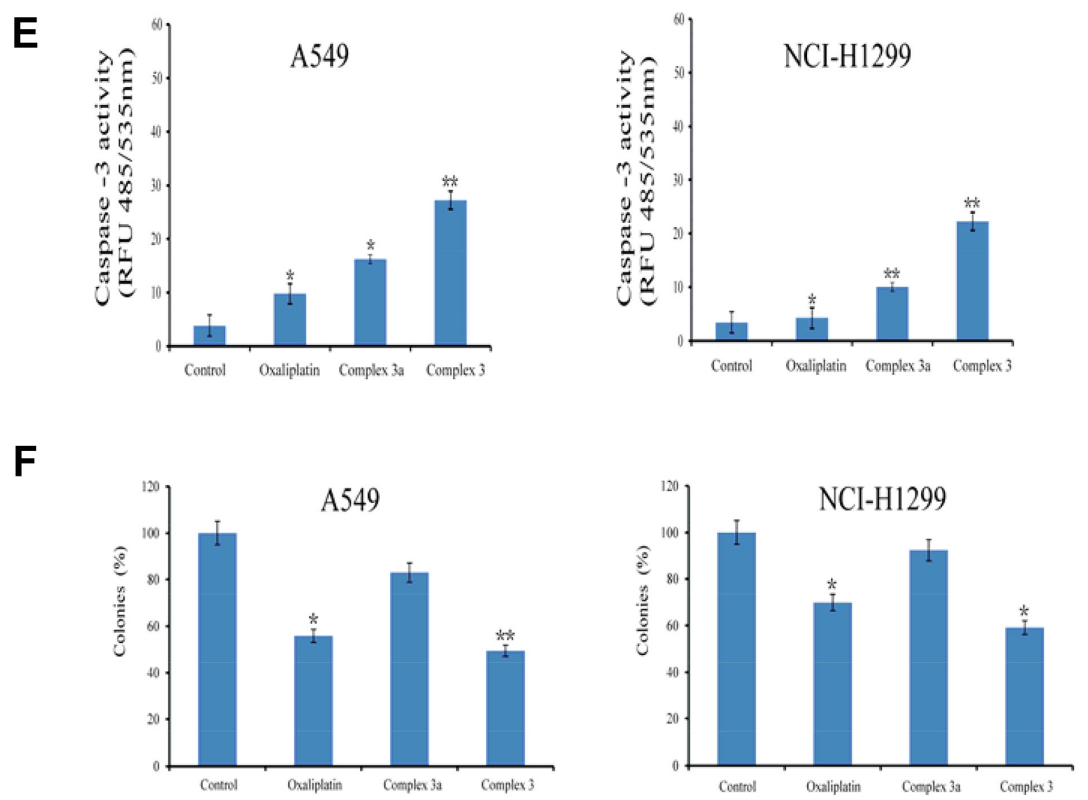

Figure 2: Cellular responses of oxaliplatin, complex 3 and complex 3a in A549 and NCI-H1299 cancer cells. All the complexes were used at the fixed concentration of $10 \mu \mathrm{M}$ for $24 \mathrm{~h}$. (A) The growth inhibition effect of complex 3 on A549 and NCI-H1299 cancer cells on 12, 24, 48 and $72 \mathrm{~h}$. (B) Apoptosis inducing property of the measured complexes by Annexin V-FITC/PI staining of cancer cells. The Y-axis shows the PI-labeled population and the X-axis shows FITC-labeled Annexin V-positive cells. (C) Morphological changes in A549 and NCI-H1299 cancer cells were observed under an inverted light microscope (original magnification $100 \times$ ). (D) Apoptotic cells were observed by DAPI staining. (E) Analysis of caspase-3 activation in cancer cells following the treatment of measure compounds. (F) Long-term colony formation assays of A549 and NCI-H1299 cancer cells. Cells were grown in the presence of the measured complexes for 7 days. For each cell line, all dishes were fixed at the same time, stained and analyzed. Results are representative of at least three independent experiments and shown as the mean \pm S.D. $* P<0.05$, ${ }^{*} P<0.01$ compared with control group. 
that complex 3 could affects long-term clonogenic survival of NSCLC cells. Taken together, these experiments demonstrate that complex 3 could induce cell apoptosis in NSCLC cells and suppress long-term clonogenic survival.

\section{Complex 3 arrested cell cycle and decreased the mitochondrial membrane potential $(\Delta \Psi \mathrm{m})$ in NSCLC cells}

To further study the effect of the measured complexes on cell cycle arrest, PI staining assays were performed to analyze the cell cycle distribution of NSCLC cells treated with oxaliplatin, complex 3 and complex $3 \mathrm{a}$ at $10 \mu \mathrm{M}$. The results in Figure 3A shown that the G2/M phases of A549 and NCI-H1299 were blocked strikingly as exposed to complex 3 compared to complex $3 \mathrm{a}$, while $\mathrm{S}$ phases were blocked as treated by oxaliplatin. With the untreated A549 and NCI-H1299 cells, the percentage of cells in the G1 phase was at $21.29 \%, 18.96 \%$ with $15.28 \%$, $22.94 \%$ in the G2/M phase, respectively. After treatment with complex 3, the percentage of cancer cells in the G1 phase increased to $57.85 \%$ and $60.29 \%$. The cell cycle arrest induced by complex 3 compared favorably to the cells treated with oxaliplatin. The results also indicated that the large steric hindrance of complex 3 could increase cell cycle arrest as compared to its mono-substituted complex $3 \mathrm{a}$.

To further study the detailed process of apoptosis induced by complex 3 in NSCLC cells, we examined the mitochondrial membrane potential $(\Delta \Psi \mathrm{m})$, which is an important proapoptotic index for early apoptosis. We chose a mitochondria-specific and voltage-dependent fluorescent probe, JC-1, to observe whether there was loss in $\Delta \Psi \mathrm{m}$. The results in Figure 3B, exposure to complex 3 of $10 \mu \mathrm{M}$ for $24 \mathrm{~h}$ resulted in elevation in the percentage of cells with green fluorescence in A549 and NCI-H1299 cancer cells, which indicated a remarkable decrement of $\Delta \Psi \mathrm{m}$ in complex 3-treated cells. The results from flow cytometry shown that complex 3 could make $\Delta \Psi \mathrm{m}$ decrease mostly compared with oxaliplatin (Figure 3C).

Since ATP production is a significant consequence attributed to the dysfunction of mitochondrial energy production, we measured intracellular ATP levels after complex 3 treatment. As shown in Figure 3D, the ATP level in cells treated with complex 3 at $10 \mu \mathrm{M}$, decreased to $19.95 \%, 31.89 \%$ of untreated A549 and NCI-H1299 cancer cells, respectively, which is $28.62 \%$ and $22.71 \%$ lower than that of oxaliplatin-treated cancer cells.

\section{Complex 3 increased $\mathrm{ROS}$ and $\mathrm{H}_{2} \mathrm{O}_{2}$ generation of NSCLC cells}

As excessive ROS generation is associated with cellkilling activity [31], we further examined whether complex 3 could also induce the formation of excessive ROS in A549 and NCI-H1299 cancer cells. Cancer cells were exposed to $10 \mu \mathrm{M}$ oxaliplatin, complex 3 and complex $3 \mathrm{a}$ and then fluorescence intensity was detected in response to the levels of ROS using DCF-DA by flow cytometry. As shown in Figure 3E, fluorescence intensity was increased rapidly in complex 3-treated groups, indicating that complex 3 induced the production of significant amounts of ROS in A549 and NCI-H1299 cancer cells. Taking into account that among all ROS and other oxygenderived free radicals, $\mathrm{H}_{2} \mathrm{O}_{2}$ has been recently suggested to act as a central player in signal transduction pathways [32], we evaluated $\mathrm{H}_{2} \mathrm{O}_{2}$ generation by a fluorometric assay in cancer cells incubated in the presence of $10 \mu \mathrm{M}$ oxaliplatin, complex 3 and complex $3 \mathrm{a} . \mathrm{H}_{2} \mathrm{O}_{2}$ measurement was carried out after $2 \mathrm{~h}$ incubations with oxaliplatin, complex 3 and complex $3 \mathrm{a}$, respectively. The production of $\mathrm{H}_{2} \mathrm{O}_{2}$ was significantly higher in cancer cells incubated with complex 3 than that in cells treated with complex 3a and oxaliplatin in A549 and NCI-H1299 cancer cells (Figure 3F). The results strongly suggested that complex 3 could induce increased intracellular oxidative stress compared with complex $3 \mathrm{a}$ and oxaliplatin, thus triggering NSCLC cancer cell apoptotic pathways.

\section{Complex 3 induced ROS-mediated DNA damage in $\mathbf{A 5 4 9}$ cells}

Following the complex 3 treatment, we measured intracellular GSH levels in A549 cancer cells. As shown in Figure 4A, while treating with complex 3, however, intracellular GSH levels did significantly reduce, which could be ceased by NAC treatment. These results proved that complex 3 reduces intracellular GSH levels to improve active platinum delivery to the DNA to interact with cellular components and causes severe DNA damage $[33,34]$. Agarose gel electrophoresis was applied to study the interaction of pET28a plasmid DNA with oxaliplatin, complex $3 \mathrm{a}$ and complex 3 . The tested complexes were incubated with DNA at different concentrations. In the electrophoretogram (Figure 4B), untreated pET28a plasmid DNA mainly consisted of covalently closed circular (Form I) and a small amount of nicked (Form II) bands. Owing to the unwinding of pET28a plasmid DNA, a decrease in the rate of migration for closed circular DNA (Form I) was observed for oxaliplatin. Moreover, a coalescence of the closed circular DNA (Form I) and open circular DNA (Form II) was observed for complex 3 , indicating a strong unwinding of the supercoiled DNA. However, no migration was observed for complex 3a, which is probably due to the fact that the large steric hindrance of complex 3 greatly increases the interaction between the complex and DNA.

As a key role in oxidative stress, ROS can directly interact with cellular components and causes severe DNA damage $[34,35]$. Thus, we further identified whether the increased ROS level serves as a cause of DDR. Based on comet assay, our data showed a proportionate increase 
A
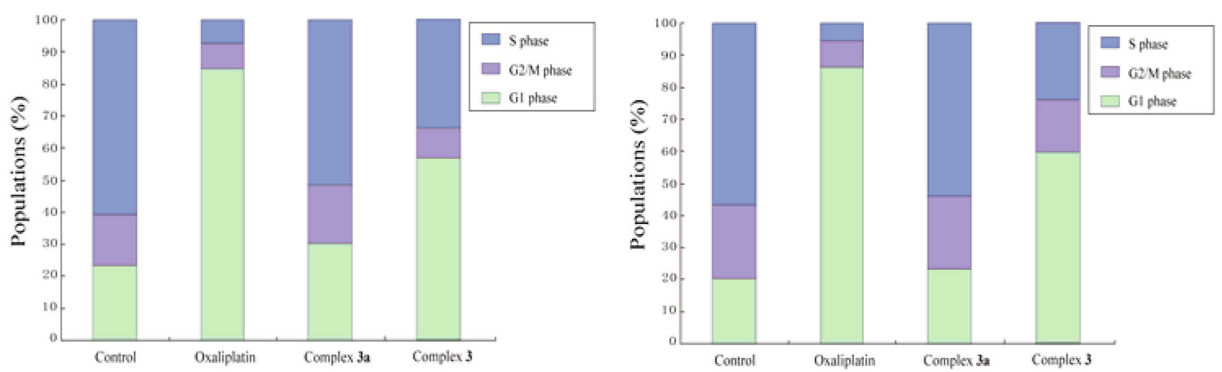

B

A549

NCI-HI299
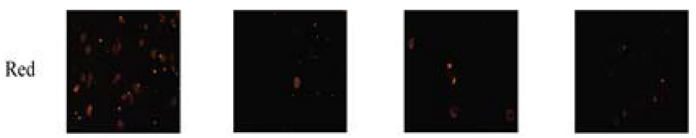

A549
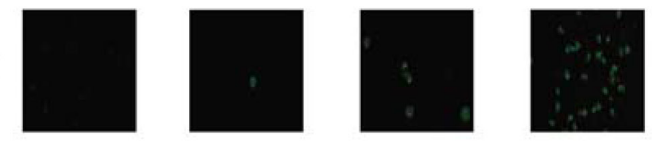

C

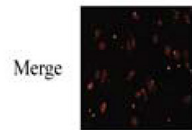

Control

Red

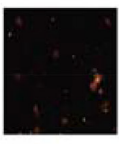

NCI-H1299 Blue
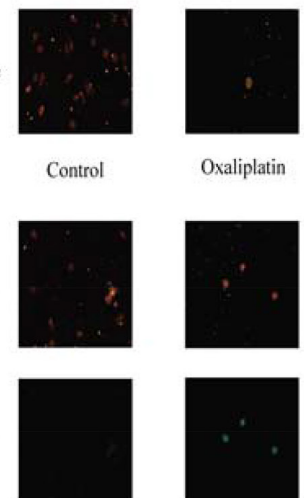

Oxaliplatin
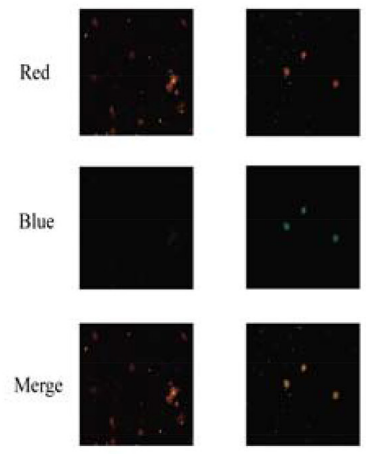

Control

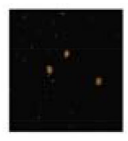

Oxaliplatin

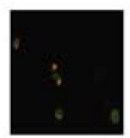

Complex 3a
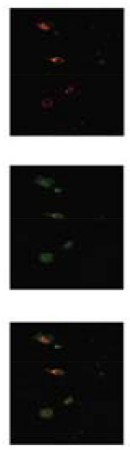

Complex 3a
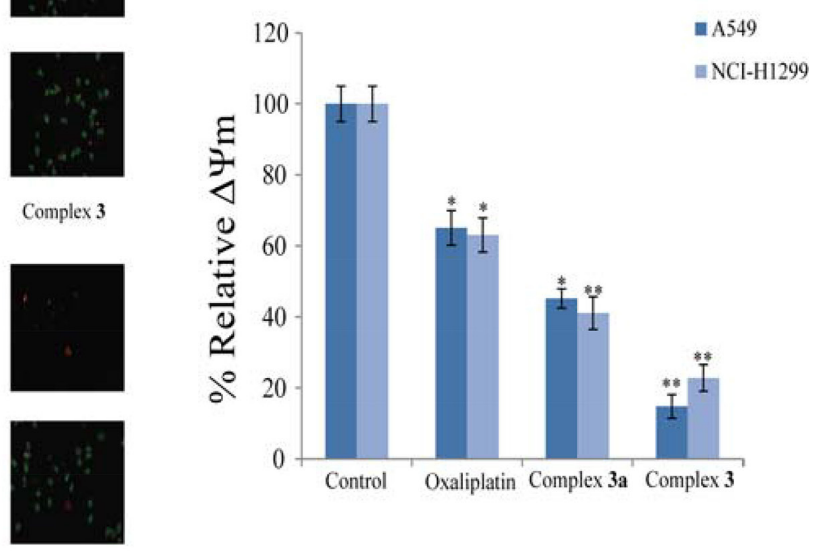

D

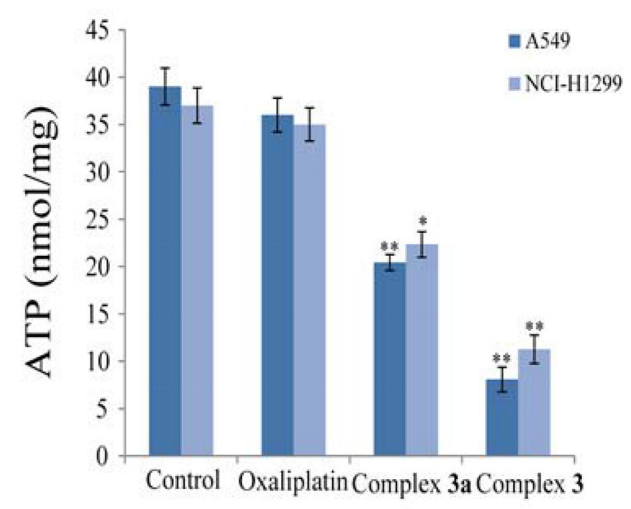

E

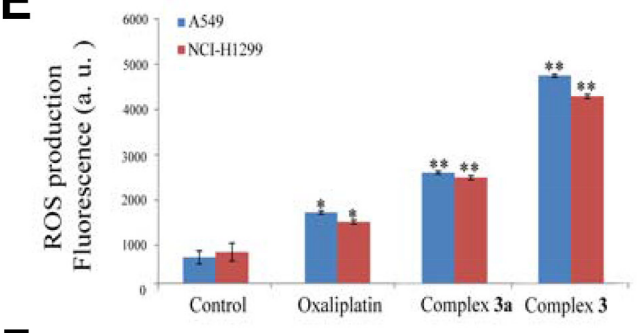

F

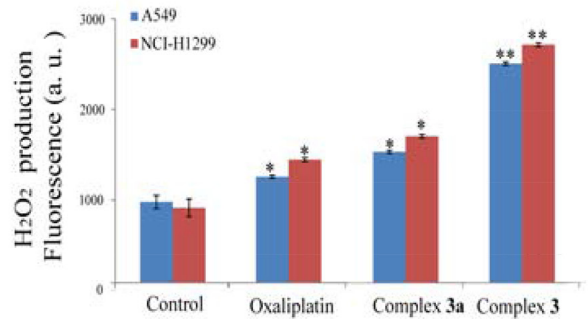


Figure 3: Complex 3 induces cell death and cell cycle changes in A549 and NCI-H1299 cancer cells. (A) Cell cycle analysis upon exposure to complex 3. A549 and NCI-H1299 cancer cells exposed to the measured complexes for $72 \mathrm{~h}$ were stained with propidium iodide and subjected to flow cytometry analysis. The mitochondrial membrane potential (b, c) and the intracellular ATP (d) decreased in complex 3-treated A549 and NCI-H1299 cancer cells. (B) Cells were exposed to oxaliplatin, complex 3 and complex 3a (10 $\mu$ M) for 24 $\mathrm{h}$, stained with JC-1 and visualized under an inverted fluorescence microscope. Red fluorescence of JC-1 dimers was present in the cell areas with high MMP, while green fluorescence of JC-monomers was prevalent in the cell areas with low MMP. (C) Normalized JC-1 fluorescence change analyzed by flow cytometry. The median fluorescence intensity of each treatment group was normalized to the control group. (D) Cells were treated with oxaliplatin, complex 3 and complex $3 \mathrm{a}(10 \mu \mathrm{M})$, for $12 \mathrm{~h}$ and then the intracellular ATP was detected. (E) Intracellular ROS were measured by flow cytometry after $10 \mu \mathrm{M}$ DCFH-DA staining. Geometric mean off luorescence intensity values were calculated and compared to that in DMSO controls. (F) Cells were exposed to $10 \mu \mathrm{M}$ oxaliplatin, complex 3 and complex $3 \mathrm{a}$, then $\mathrm{H}_{2} \mathrm{O}_{2}$ level was measured. Values are means \pm SD for at least three independent experiments performed in triplicate $(* P<0.05$ and $* * P<0.01$ compared with vehicle control).

in three major parameters of comet assay (tail moment, olive tail moment and tail length) as time passed in complex 3-treated cells, whereas these indicators showed minor changes when cells were pre-treated with NAC (Figure 4C). To investigate the extent of DNA damage induced by complex 3, we detected the numbers of normal SSB using an alkaline elution assay. The results observed in cancer cells treated with the tested complexes at $10 \mu \mathrm{M}$ in 15, 30 and $60 \mathrm{~min}$ indicated that complex 3 could effectively increase the numbers of SSBs, which could not be inhibited by NAC treatment (Figure 4D). However, complex 3 was found to induce higher DNA damage levels of SSBs than oxaliplatin and complex 3a, implying that with the time-dependent DNA repair response of SSBs, the increased DNA damage level happened in complex 3 -treated cancer cells.

\section{Complex 3 induced ROS-mediated DNA double strand breaks and blocked DNA repair response in $\mathbf{A 5 4 9}$ cells}

The serine 139-phosphorylated form of chromatinassociated histone $\mathrm{H} 2 \mathrm{AX}$, namely $\gamma-\mathrm{H} 2 \mathrm{AX}$, is a key marker of cellular response to DDR, particularly DSBs. We detected obvious increases in $\gamma$-H2AX when cells were exposed to complex 3 (Figure 5A). Obviously, pre-treatment of NAC could considerably alleviate the DDR triggered by complex 3 (Figure 5B). Therefore, we came to a conclusion that complex 3 caused DDR especially DSBs in A549 cells, which might happen after the increased level of intracellular ROS. In order to reveal the mechanisms underlying the enhanced DNA damage, complex 3 was studied to learn whether it could reduce the activation of DNA repair response including the colocalization of DSB repair protein MDC1/Aprataxin within nucleus. Treatment of A549 cells with $10 \mu \mathrm{M}$ complex 3 for $24 \mathrm{~h}$ led to a dramatically decrease in the co-localization of MDC1/Aprataxin to the damaged DNA (Figure 5C). The different fluorescence intensities of MDC1/Aprataxin induced by oxaliplatin, complex 3 and complex 3a, respectively, indicated that DSBs happened mostly in the treatment with complex 3 . In order to reveal the mechanisms underlying DNA damage, complex 3 was studied to detect whether it could suppress the activation of DNA single strand break repair via the phosphorylation of SSB repair mediator/adaptor proteins XRCC1 within nucleus. Treatment of A549 cells with $10 \mu \mathrm{M}$ complex 3 for $24 \mathrm{~h}$ resulted in the suppression of phosphorylation of XRCC1 compared with oxaliplatin (Figure 5D). The results revealed that complex 3 could inhibit extensive DNA damage repair in addition to its ability of increasing cellular Pt uptake.

\section{Complex 3 induced autophagy in cells death}

The role of complex 3-induced autophagy in cell death was further analyzed (Figure 6). When A549 cancer cells were treated with complex 3 of $10 \mu \mathrm{M}$, the protein expression of LC3-II was increased (Figure 6A). Compared to the complex 3-treated group, exposure of A549 cells to oxaliplatin and complex $3 \mathrm{a}$ of $10 \mu \mathrm{M}$ decreased the level of LC3-II from 2.5- to 1.3-folds (Figure 6B). Treatment with complex 3 for $24 \mathrm{~h}$ caused a 4.5 -folds increase in cells undergoing autophagy (Figure 6C). In contrast, when A549 cells were treated with $10 \mu \mathrm{M}$ oxaliplatin and complex $3 \mathrm{a}$, the number of autophagic cells was decreased. After A549 cells treated with oxaliplatin, complex $3 \mathrm{a}$ and complex 3 for $24 \mathrm{~h}$, the percentage of autophagic cell apoptosis decreased from $21.9 \%$ to $41.5 \%$ (Figure 6D). Subsequently, complex 3 resulted in a decrease in cell viability. Moreover, Bax and Bcl-2 expressions were measured by western blot analysis of whole cell lysates. Incremental changes in proapoptotic Bax and decreased changes anti-apoptotic Bcl-2 protein levels were also observed (Figure 6E), suggesting that complex 3 may modulate apoptosis in A549 lung cancer cells.

\section{Complex 3 suppressed the activation of PI3K/ Akt/mTOR signaling pathways in autophagic cells death}

The mammalian target of rapamycin (mTOR) kinase is used to regulate autophagy as controlled though oxidative stress, hypoxia and growth receptors [36]. The phosphatidylinosital-3 kinase (PI3K)/Akt signaling pathway activates mTOR through phosphorylating and inactivating the tuberous sclerosis complex (TSC) $1-\mathrm{TSC} 2$ complex [37]. Inhibition of mTOR results in activation of autophagy [38]. Thus, treatment of A549 cells with $10 \mu \mathrm{M}$ oxaliplatin, complex 3 and complex $3 \mathrm{a}$ for $24 \mathrm{~h}$ inhibited 
A

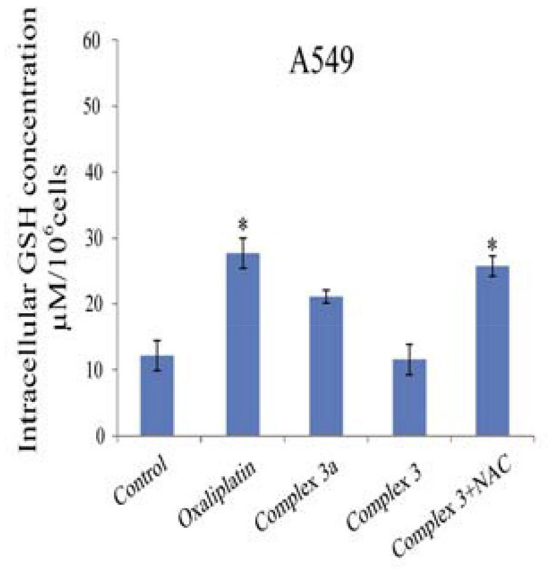

C A549

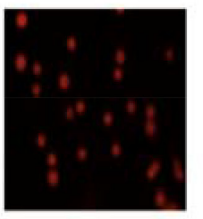

Control

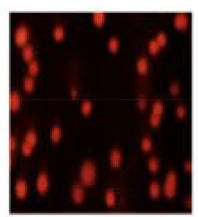

Oxaliplatin

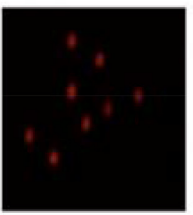

Complex 3a
B

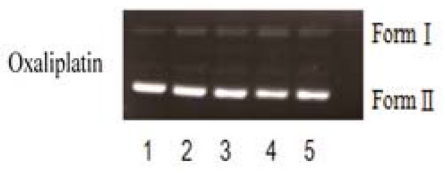

Complex 3

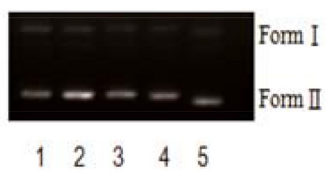

Complex 3

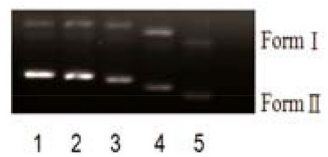

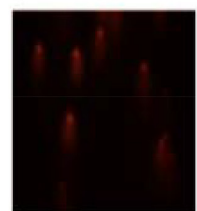

Complex 3

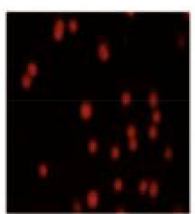

Complex 3

(NAC pretreated)

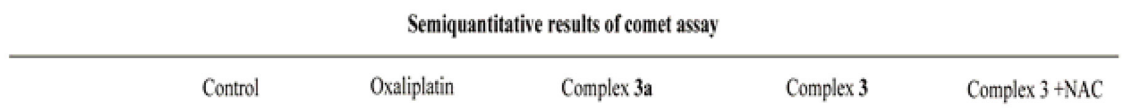

Tail Length $6.26 \pm 1.59 / 9.92 \pm 1.28 \quad 12.35 \pm 3.15 / 23.27 \pm 5.25 \quad 26.25 \pm 10.79 / 23.75 \pm 9.35 \quad 50.45 \pm 18.39 / 32.45 \pm 12.96 \quad 23.65 \pm 11.25 / 19.63 \pm 8.15$

\begin{tabular}{|c|c|c|c|}
\hline Tail Moment $0.97 \pm 0.25 / 1.28 \pm 0.37 \quad 0.75 \pm 0.09 / 2.15 \pm 0.47$ & $6.52 \pm 0.94 / 3.93 \pm 0.23$ & $16.17 \pm 7,91 / 9,35 \pm 3.32$ & $4.72 \pm 2.06 / 2.98 \pm 1.21$ \\
\hline a Tail Moment $0.27 \pm 0.02 / 0.12 \pm 0.012 .57 \pm 0.46 / 1.67 \pm 0.75$ & $2.09 \pm 1.57 / 1.06 \pm 0.76$ & $7.91 \pm 2.41 / 1.19 \pm 0.93$ & $2.12 \pm 0.24 / 3.74 \pm 0$ \\
\hline
\end{tabular}

D

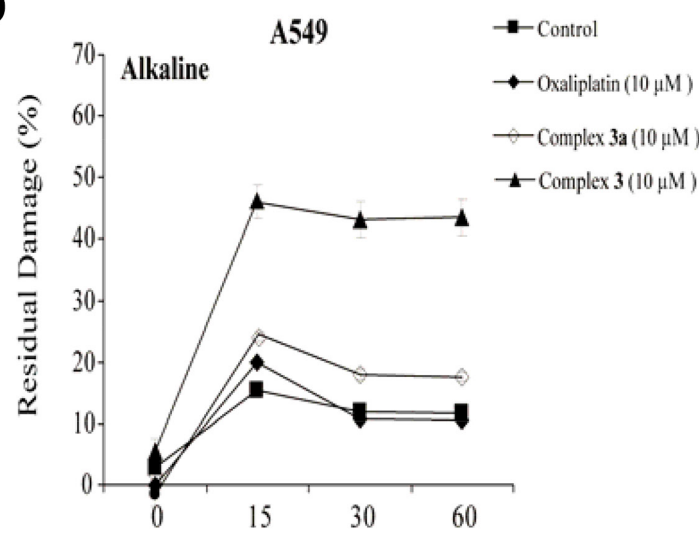

Repair times(min)

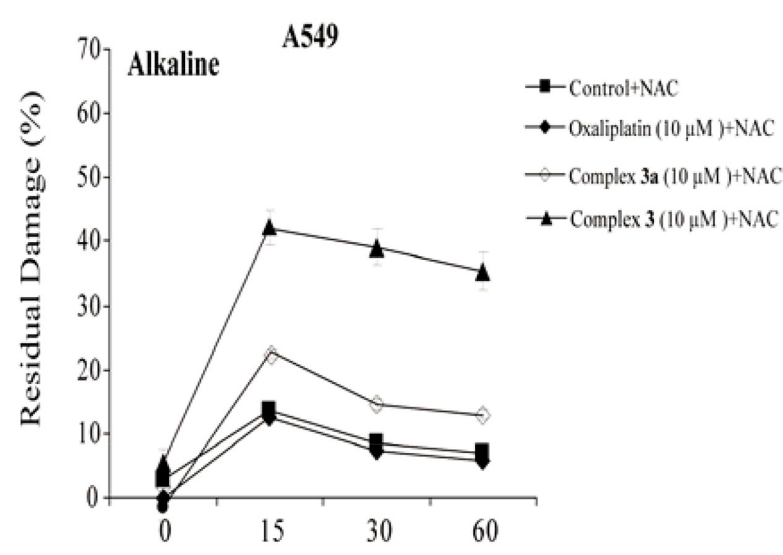

Repair times(min)

Figure 4: Intracellular GSH concentrations and DNA damage of the measured complexes induced SSBs and DSBs. (A) A549 cells were pretreated with NAC for $30 \mathrm{~min}$ and then incubated with oxaliplatin, complex 3 and complex $3 \mathrm{a}(10 \mu \mathrm{M})$ for $4 \mathrm{~h}$. (B) Gel electrophoretic mobility pattern of pET28a plasmid DNA incubated with various concentrations of platinum(II) complexes. Lanes $1-5$ (0, 20, 80, 320, $640 \mu \mathrm{M}$ ) + DNA. A) oxaliplatin; B) complex 3a; C) complex 3. (C) Comet assay revealing increased chromosomal DNA strand breaks including SBBs, DSBs and active excision repair of DNA cross-links triggered by the measured complexes in A549 cancer cells with or without NAC pretreatment. (D) The number of SBBs was determined by a neutral comet assay with or without NAC pretreatment. Graph represents average number of foci per cells \pm SD. Results are representative of at least three independent experiments and shown as the mean \pm S.D. $* P<0.05, * * P<0.01$ compared with control group. 
the protein levels of PI3K to 1.01-, 1.25- and 0.42-folds, respectively (Figure 7A). At the same time, levels of the p-Akt protein decreased to 0.95-, 1.02-, and 0.39-folds, respectively (Figure 7B). Moreover, amounts of p-mTOR were also decreased to 1.15-, 1.41-, and 0.69-folds (Figure 7C). As a results, the administration of complex 3 decreased levels of proteins in PI3K/Akt/mTOR signaling pathways.

\section{Complex 3-induced autophagy were mediated by ROS in A549 cells}

To investigate the role of ROS in complex 3-induced cell death, the level of intracellular $\mathrm{H}_{2} \mathrm{O}_{2}$ was measured. After exposure of A549 cancer cells to $10 \mu \mathrm{M}$ complex 3 , the increased level of the LC3-II protein was also reduced by NAC (Figure 8A). Exposure of A549 cells to NAC reduced levels of LC3-II from 2.3- to 1.5-folds (Figure 8B). Consequently, pretreatment with NAC decreased the percentage of autophagy from $42.5 \%$ to $11.8 \%$ (Figure $8 \mathrm{C}$ ), and the percentage of apoptosis from $52.5 \%$ to $34.2 \%$ (Figure $8 \mathrm{D}$ ). In parallel, the complex 3 -induced increase ratio of $\mathrm{Bax} / \mathrm{Bcl}-2$ was suppressed by NAC (Figure 8E). Moreover, pretreatment with NAC in complex 3a-treated A549 cancer cells showed no decreased percentage of autophagy (Figure 8F) and apoptosis (Figure 8G).

\section{Complex 3 inhibited tumor growth and autophagy in the mice xenograft model}

To evaluate the anti-tumor effect of complex 3 in vivo, an xenografts nude mice model of A549 cancer cells was performed. Oxaliplatin (dosed intravenously at $5 \mathrm{mg} / \mathrm{kg}$ twice a week), complex 3 (dosed intravenously at $5 \mathrm{mg} / \mathrm{kg}$ once every three days), complex 3a (dosed intravenously at $5 \mathrm{mg} / \mathrm{kg}$ once every three days) were conducted into seven nude mice groups. There was no any death during the tumor formation in nude mice. The statistical results indicated that the tumor volumes (Figure 9A) in complex 3-treated group were significantly decreased compared to the same dosage of cisplatin-treated group. At the end of treatments, the tumor weight was measured to detect the antitumor activity of these measured groups. The tumor growth inhibition rate of complex 3 reached $67.96 \%$, while that of oxaliplatin at the same dose as complex 3 was only $34.48 \%$ (Figure 9B). Because platinum-based drugs are well known for their toxic effects on the mean bodyweights of treated animals, the toxicity of complex 3 in the body weights of mice was assayed. The results in Figure 9C illustrated that the increase of bodyweights was observed in the treatment of complex 3 , however, oxaliplatin exerted a continuous decrease of bodyweights. The mice treated with the tested
A

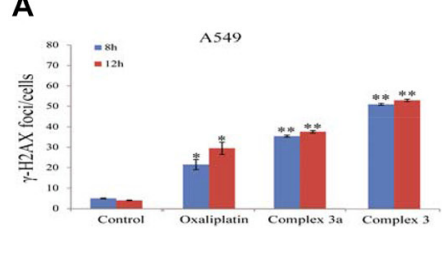

C

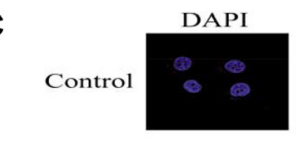

Oxaliplatin
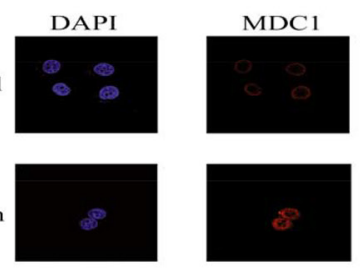

Complex 3
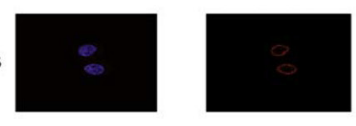

Complex 3a

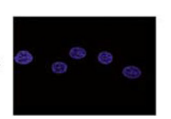

B

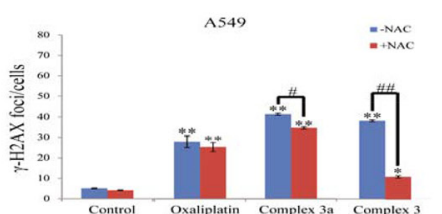

D

Control
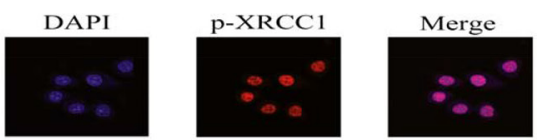

Oxaliplatin
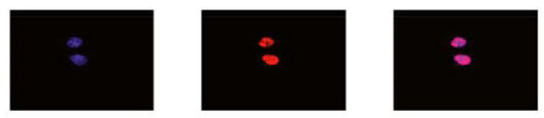

Complex 3
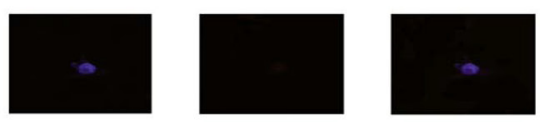

Complex 3a
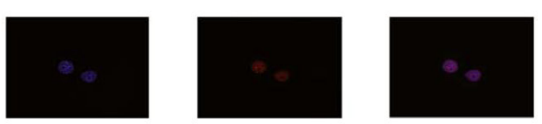

Figure 5: The inhibitory effect of the measured samples on DNA repair response. (A) $\gamma \mathrm{H} 2 \mathrm{AX}$ foci after treatments were counted in 50-60 individual cells of $8 \mathrm{~h}$ and $12 \mathrm{~h}$ in A549 cells. (B) $\gamma \mathrm{H} 2 \mathrm{AX}$ foci after pretreatment with NAC were counted in 50-60 individual cells of $12 \mathrm{~h}$ in A549 cells. (C) Complex 3 could inhibit the recruitment of DSB repair proteins MDC1 and Aprataxin to damaged chromatin. (D) The inhibitory effect of the measured samples on DNA single strands repair response. A549 cancer cells were treated with the measured complexes at $10 \mu \mathrm{M}$ for $24 \mathrm{~h}$. After that, cells were pre-extracted with detergent, fixed and immunostained with antibodies against MDC1/Aprataxin and p-XRCC1. Results are representative of at least three independent experiments and shown as the mean \pm S.D. $* P<0.05,{ }^{* *} P<0.01$ compared with control group. 
complex 3 were selected for histological analyses. The side effects of complex 3 decreased significantly can be explained by the in vivo distribution behaviors. The level of Pt in liver, spleen, lung and kidney were significantly reduced as the drug tumor distribution was significantly increased when mice were injected with complex 3 (Figure 9D). The HE staining of slices from liver and kidney demonstrated that complex 3 had hardly toxic effect on normal tissues in contrast to cisplatin (Figure 9E). After administration of measured complexes, complex 3 increased expressions of LC3 in tumor tissues (Figure 9F) which the in vivo effect of complex 3 on inducting autophagy was also evaluated. These data proved that complex 3 exhibits pronounced antitumor activity with nearly no toxic effect on treated animals in contrast to oxaliplatin and complex $3 \mathrm{a}$.
A

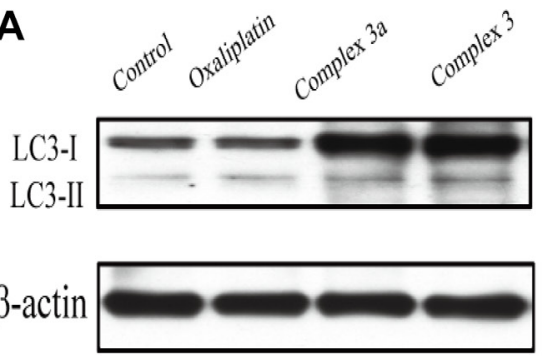

C

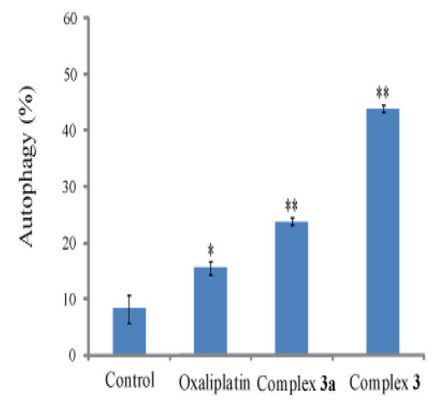

E
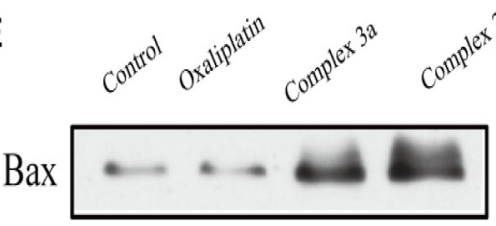

Bcl-2

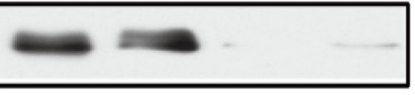

$\beta$-actin
B

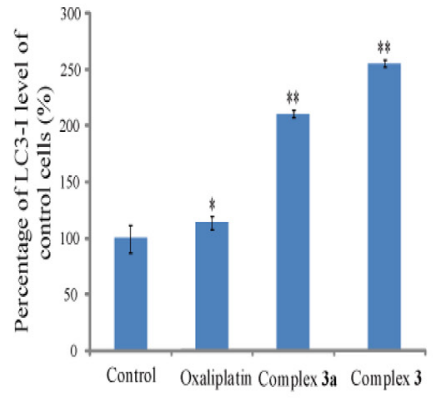

D
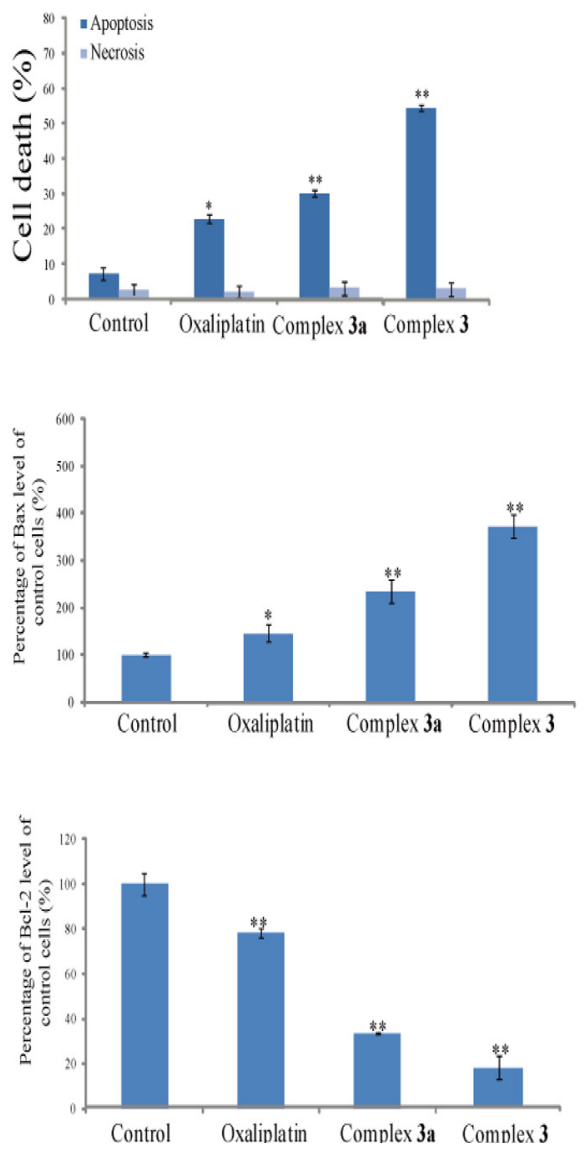

Figure 6: Complex 3 induces autophagic cell death. Human A549 cells were treated with measured complexes of $10 \mu \mathrm{M}$ for 24 h. (A) Levels of LC3 were immunodetected. $\beta$-actin was detected as the internal control. (B) These protein bands were quantified and statistically analyzed. (C) The percentage of autophagy was quantified using flowcytometry. (D) Cell apoptosis was quantified using flow cytometry. (E) Bax and Bcl-2 levels in the whole-cell lysates. Each value represents the mean \pm SEM from three independent experiments. The symbols $*$ indicate that values significantly $(* P<0.05, * * P<0.01)$ differed from the respective control group. 


\section{Pharmacokinetics}

The stability of complex 3 in blood is significantly important for its clinical application. Thus, we investigated the stability of complex 3 in rat plasma via ICP-MS measurement. Fresh rat plasma was added with a DMSO solution of complex $3(10 \mu \mathrm{M})$. After incubation for 0 , 2, 4 and $8 \mathrm{~h}$ at $37^{\circ} \mathrm{C}$, the $\mathrm{Pt}$ content in rat plasma was measured by ICP-MS. The results in Figure 9G reveals the half-life of complex 3 in rat plasma to be $27.6 \mathrm{~h}$, which is significantly longer than that of oxaliplatin $\left(t_{1 / 2} \sim 13.1 \mathrm{~h}\right)$. This interaction contributes to the promising stability of complex 3 in rat plasma.

The pharmacokinetic profile of complex 3 was performed as compared with cisplatin. The results showed that cisplatin and complex 3 followed a two-compartment
A
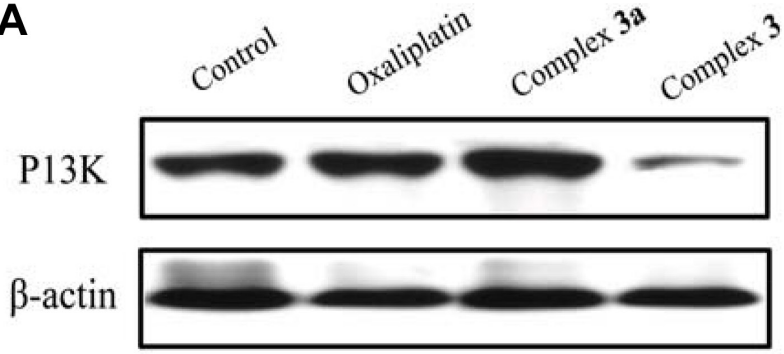

B

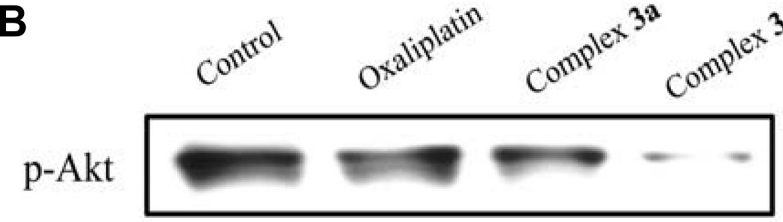

Akt

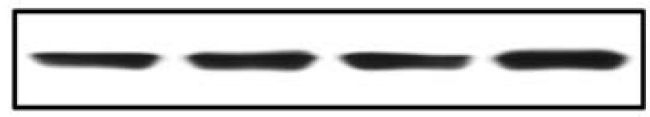

$\beta$-actin
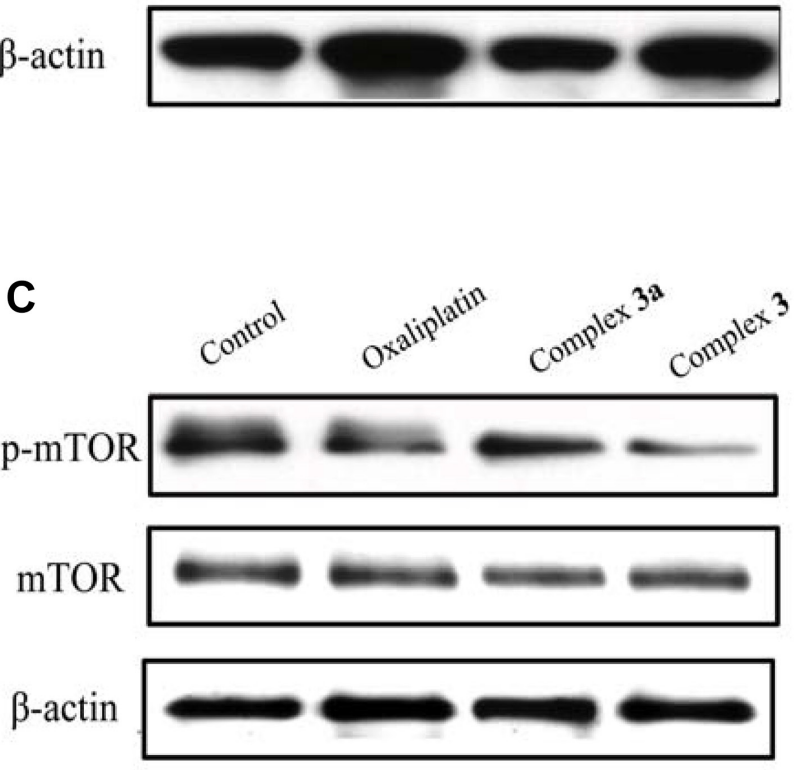
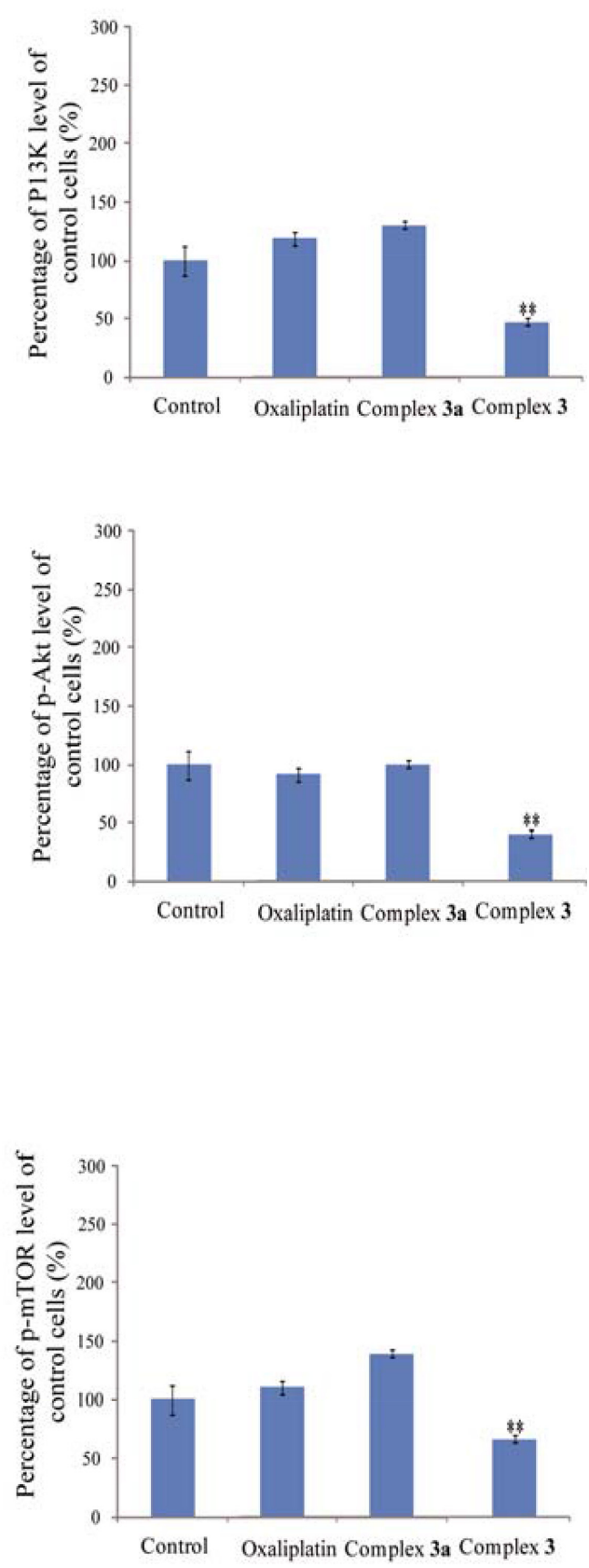

Figure 7: Complex 3 inhibits the PI3K/Akt/mTOR signaling pathway. Human A549 cells were exposed to $10 \mu \mathrm{M}$ complex 3 for 24 h. (A) Levels of PI3K was immunodetected. $\beta$-Actin was detected as an internal control. These protein bands were quantified and statistically analyzed. (B and $\mathbf{C}$ ), Levels of p-Akt and p-mTOR were immunodetected. Akt, mTOR, and $\beta$-actin were detected as the internal controls. These immunorelated protein bands were quantified and statistically analyzed. Each value represents the mean \pm SEM from three independent experiments. The symbols $*$ indicate that values significantly $\left({ }^{*} P<0.05,{ }^{*} P<0.01\right)$ differed from the respective control group. 
pharmacokinetic model, which was based on the residual sum of squares and minimum Akaike's information criterion (AIC) value. A non-compartment model was applied to analyze changes of pharmacokinetic behaviors. The results in Figure $9 \mathrm{H}$ showed the Pt concentration-time profiles in rat plasma, revealing the half-life of complex $3\left(\mathrm{t}_{1 / 2} \sim 24.5 \mathrm{~h}\right)$ to be 3.61-folds increased compared to oxaliplatin $\left(\mathrm{t}_{1 / 2} \sim 13.1 \mathrm{~h}\right)$. Although rapid elimination of $\mathrm{Pt}$ via blood circulation occurred in both cisplatin and complex 3 groups, changes of these preparations were significantly different and significant increased release time happened in the complex 3-treated group. Complex 3 had a longer
A

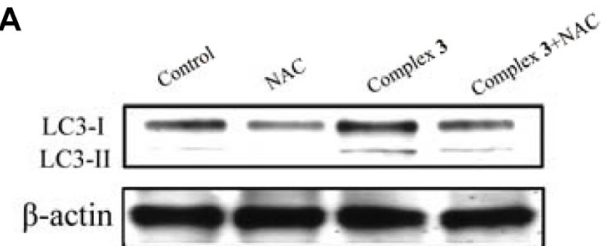

C

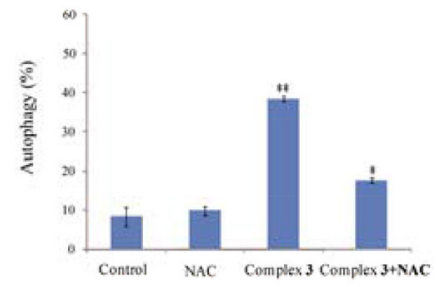

E

Bax

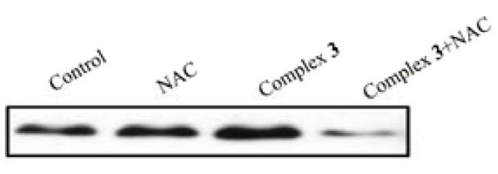

Bcl-2
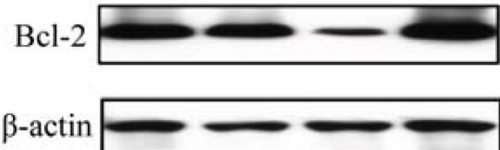

F

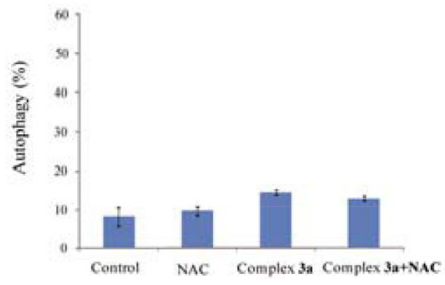

B
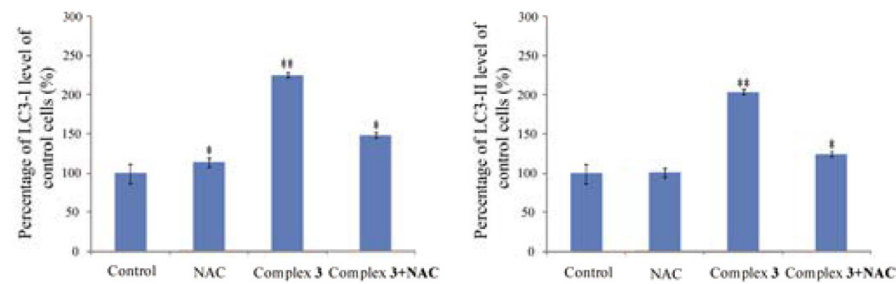

D
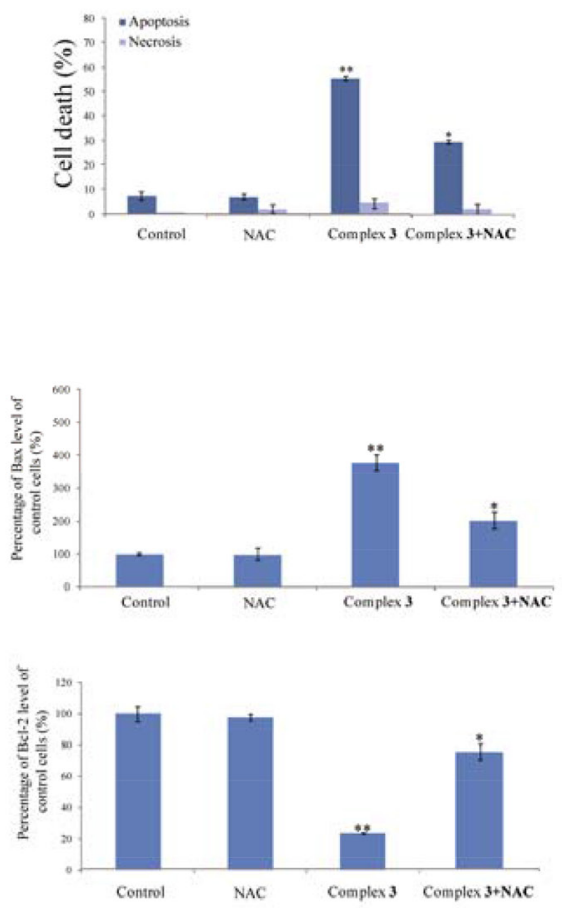

G

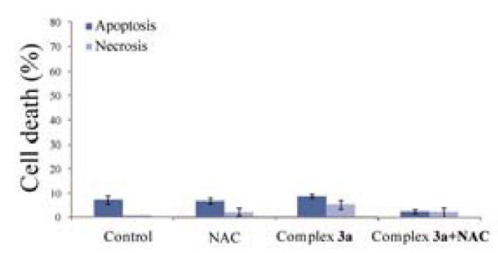

Figure 8: Reactive oxygen species (ROS) are involved in complex 3-induced autophagic death. (A) A549 cells were pretreated with $5 \mathrm{mM} \mathrm{NAC}$ for $2 \mathrm{~h}$ and then with $10 \mu \mathrm{M}$ complex for another $18 \mathrm{~h}$. Levels of LC1 and LC3 were immunodetected. $\beta$-Actin was immunodetected as the internal control. (B) These protein bands were quantified and statistically analyzed. The percentage of autophagy (C) and cell viability (D) were analyzed using flow cytometry. (E) Levels of Bax and Bcl-2 were immunodetected. $\beta$-Actin was used as the internal control. The protein bands were quantified and analyzed. (F) The percentage of autophagy was quantified using flow cytometry following the pretreatment with NAC in complex 3a-treated A549 cells. (G) Cell apoptosis was quantified using flow cytometry with NAC pretreatment in complex 3a-treated A549 cells. Each value represents the mean \pm SEM from three independent experiments. The symbols * indicate that values significantly $\left(* P<0.05,{ }^{* *} P<0.01\right)$ differed from the respective control group. 
A

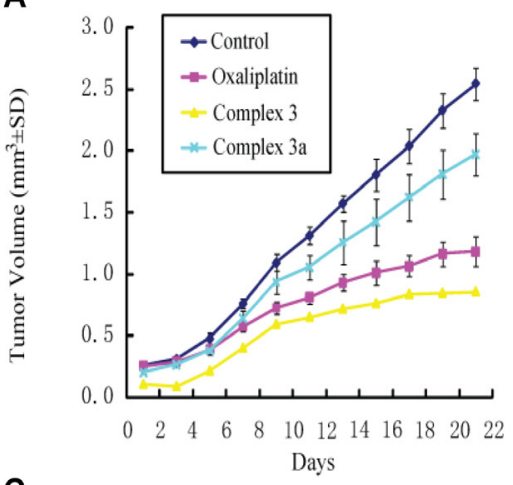

C

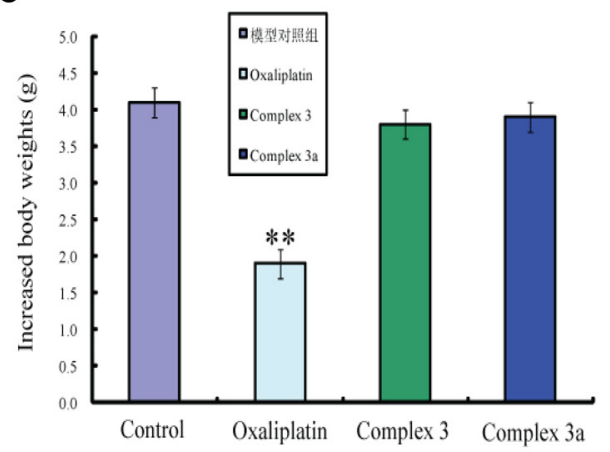

E

Liver
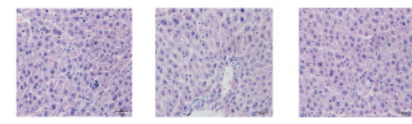

Kindey
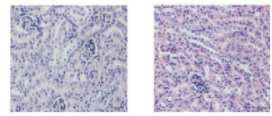

Control

Oxaliplatin

G

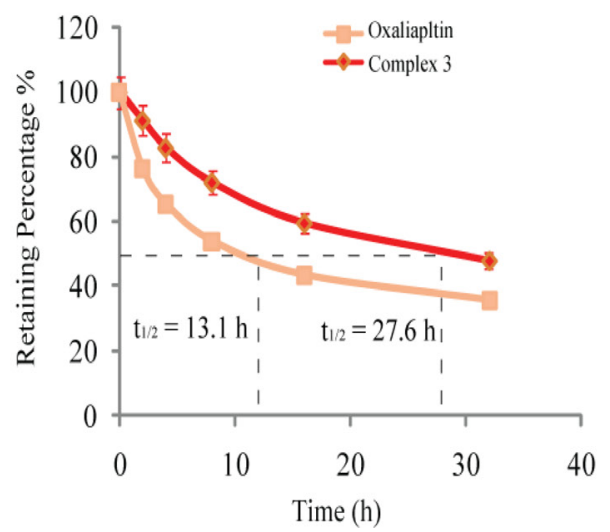

B

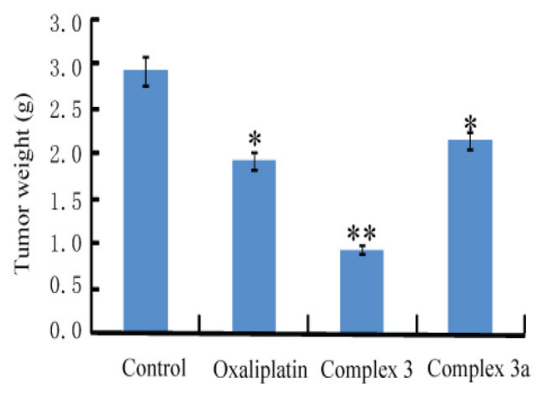

D

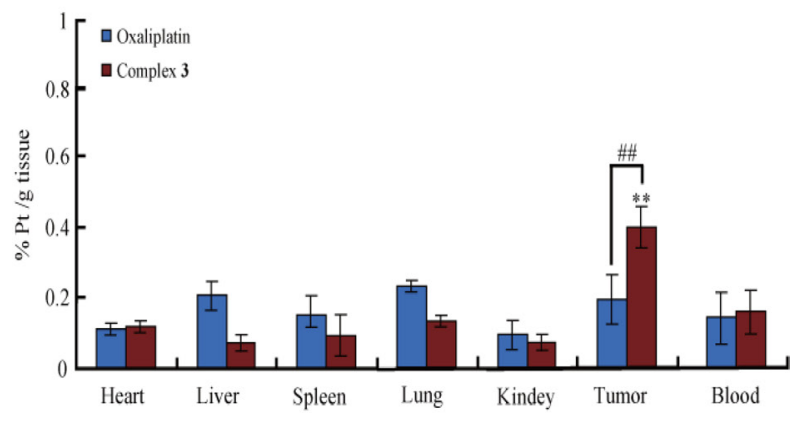

F

LC-3

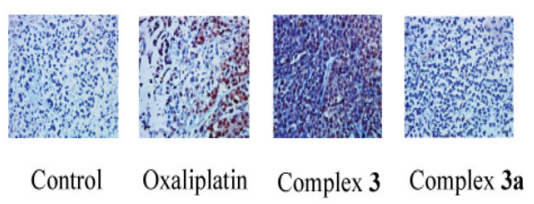

H

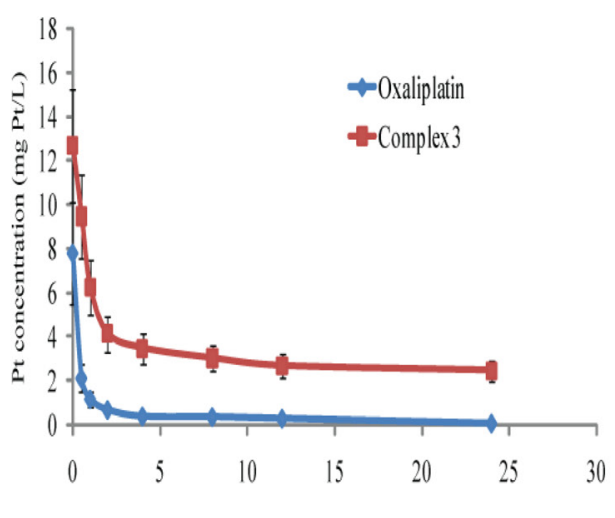

Figure 9: In vivo antitumor activity of oxaliplatin, complex 3 and complex 3a in A549 xenograft tumors. Mean tumor volumes, changes in tumor and body weights are presented. Oxaliplatin (dosed intravenously at $5 \mathrm{mg} / \mathrm{kg}$ twice a week), complex 3 (dosed intravenously at $5 \mathrm{mg} / \mathrm{kg}$ once every three days), complex 3a (dosed intravenously at $5 \mathrm{mg} / \mathrm{kg}$ once every three days). (A) The tumor growth in xenograft mouse models at the administration of the corresponding groups. (B) The tumor weight in each group at the end of the experiment. (C) Measured weight increase of mice during the treatments. (D) Tissues and tumor distribution of cisplatin and complex 3 in mice bearing A549 tumors after i.v. administration of the corresponding groups. Major organs were collected at $1 \mathrm{~h}$ after injection. (E). The HE staining of normal tissues of Liver and Kindey. (F) immunoblotting analysis of LC3. (G) Stability of oxaliplatin and complex 3 in rat plasma. (H) In vivo pharmacokinetic curves of Pt concentration in the rat plasma versus time after intracenous injection of cisplatin and complex 3 in rats. Results are representative of at least three independent experiments and shown as the mean \pm S.D. ${ }^{*} P<0.05$, ${ }^{* *} P<0.01$ compared with control group. 
blood retention as compared to cisplatin, which could dramatically promote $\mathrm{Pt}$ accumulation in tumor tissues in complex 3-treated group. The results could be attributed to the biodistribution of the complex 3 in normal tissues as well as retention in blood circulation. Thus, complex 3 with longer circulation time could significantly alleviate in vivo pharmacokinetics of cisplatin and increase its bioavailability.

Upon above all the study, complex 3, possessing significant antitumor activity via inhibiting oxidative DNA damage and autophagic responses and exhibiting nearly no toxic effect, has a potential promise to be a platinum-based anticancer drug candidate.

\section{DISCUSSION}

Platinum-based chemotherapeutics are widely used clinically via causing most human tumor regression. However, the DNA-damaged platinum-based drugs have been intensively studied for their antitumor efficacy with high levels of DNA adducts lesions, finally causing cell cycle arrest and cell death, and thus have severe toxicity and acquired resistance. Our group has previously designed a series of platinum-based complexes bearing N-monosubstituted $1 R, 2 R$-diaminocyclohexane derivatives as carrier ligands which showed optimistic antitumor activity compared with oxaliplatin. More important, we synthesized several $\mathrm{Pt}(\mathrm{II})$ complexes of $(1 R, 2 R)-\mathrm{N}^{1}, \mathrm{~N}^{2}$-dibutyl-1,2diaminocyclohexane with two n-butyl branches as steric hindrance. The data showed that the increase of sterically hindered effect of the platinum complexes could improve the cytotoxic activity and decrease the side effects, thus we intend to introduce two alkyl moieties to the $1 R, 2 R-\mathrm{DACH}$ skeleton to further study the sterically hindered effect of the platinum complexes. The study proved that complex 3 could induce oxidative DNA damage in NSCLC cells. In a continuation of those results, herein we revealed that complex 3 can induce autophagy of A549 cells in vitro and in vivo. Moreover, this study showed that suppression of ROS production could inhibit DNA damage and autophagic responses, which could consequently lower apoptosis of human lung cancer cells. Therefore, complex 3 can induce apoptosis and autophagic death of cancer cells. Apoptosis and autophagy are classified as programmed cell death and there is an interconnection between autophagy and apoptosis [39], which could result in cell death and cooperate during this process [40]. For instant, autophagy was reported to result in traumatic brain injury-induced apoptosis [41]. In this study, inhibition of autophagy by NAC decreased apoptosis and reversed cell viability. Our results suggest that complex 3-induced autophagy contributes to apoptotic cell death. On the contrary, prosurvival autophagy also occurred in some models to reduce apoptosis, such as imatinib-treated gastrointestinal stromal tumor cells and cisplatin-treated gastric cancer cells [42, 43]. Thus, the role of complex 3-induced autophagy in different cancer cells is still controversial.
Previous studies proved that the PI3K/Akt/mTOR signaling pathway is involved in autophagy induction $[43,44]$. Herein, after treating with complex 3, whether autophagy was induced and was accompanied by reduced protein levels of PI3K, p-Akt and p-mTOR should be further studied. Additionally, hypoxia has been shown to regulate autophagy of cancer cells [45]. Previous stuides reported that a combined treatment with celecoxib and $\gamma$-irradiation could synergistically induce autophagy of hypoxic cancer cells [46]. Thus, hypoxia may be another critical factor that can synergistically induce autophagy of cancer cells with complex 3 . In addition to cell cycle arrest, senescence, and apoptosis, p53 can stimulate autophagy [47]. Activation of p53 results in upregulation of unc51-like kinase $1 / 2$, which is necessary for sustained autophagy in response to camptothecin-induced DNA damage [48]. However, determining how p53 regulates autophagy after complex 3 treatment requires further investigation.

Numerous studies have demonstrated that increased ROS stress in cancer cells leads to apoptosis [49]. However, other studies indicated that ROS participate in autophagy to regulate cell survival. A novel celecoxib derivative, OSU-03012, induced ROS-related autophagic cell death in hepatocellular carcinoma [50]. Silibinin triggered ROS generation, including $\mathrm{H}_{2} \mathrm{O}_{2}$ and $\mathrm{O}^{2 \cdot-}$, to induce autophagic and apoptotic cell death of HT1080 human fibroblast cells [51]. In this study, ROS and $\mathrm{H}_{2} \mathrm{O}_{2}$ were generated after treatment with complex 3 and were suppressed by NAC, resulting in a decrease in autophagic and apoptotic cell death of A549 cells. Our results showed that complex 3-induced autophagy contributes to A549 cancer cell death through ROS generation. This study suggests that ROS may cause cell death via apoptosis and autophagy. However, the role of ROS-induced autophagy in cell death is still controversial. DNA damage induced by ROS and chemotherapeutic agents promotes p53 activation, which causes caspase-dependent apoptosis and poly (ADPribose) polymerase-1-mediated necrosis [52]. Those studies showed that interlinks between ROS and p53 are complex, and outcomes may be determined by various stimuli or cell types.

In our present study, we designed, synthesized and characterized a series of platinum(II) complexes with $(1 R, 2 R)-\mathrm{N}^{1}, \mathrm{~N}^{2}$-diisobutyl-1,2-diaminocyclohexane as a carrier ligand and chloride and dicarboxylates as leaving groups. The in vitro cytotoxicity study revealed that complex 3 had significant cytotoxicity effect against all the tested cell lines compared to its mono-substituted complex $3 \mathrm{a}$, indicating that the function of alkyl moieties, as steric hindrance, has a significant influence on the antitumor property of the resulting platinum complexes. The flow cytometric assay indicated that complex 3 could induce increased apoptotic rate and ROS generations of 
cancer cells compared to oxaliplatin. The comet assay and $\gamma \mathrm{H} 2 \mathrm{AX}$ foci assay proved its activity to induced DNA damage including double strand breaks obviously, which could be ceased by ROS scavenger NAC in A549 cells. Meanwhile, our results proved for the first time that treating A549 cells with complex 3 induced ROS-mediated autophagic cell death. Additionally, NAC, an antioxidant, improved cell survival by inhibiting autophagy and apoptosis, which indicates the important role of ROS in regulating complex 3-induced cell death. Therefore, this study showed the unique structure of large steric hindrance could enhance its antitumor activity higher compared to oxaliplatin via ROS-mediated DNA damage and autophagic cell death. Consequently, the introduction of appropriate alkyl moieties to the $1 R, 2 R$-DACH skeleton as steric hindrance can be a candidate to design platinum complexes in future study.

\section{MATERIALS AND METHODS}

\section{Materials and instruments}

All chemicals and solvents were of analytical reagent grade and were used without further purification. Potassium tetrachloroplatinate(II) was obtained from a local chemical company. The ligand was prepared by the method as described previously in our laboratory. Silver dicarboxylates were prepared by the reaction of the corresponding sodium dicarboxylate with silver nitrate in water. Infrared spectra were measured on $\mathrm{KBr}$ pellets on a Nicolet IR200 FT-IR spectrometer in the range of $4000-400 \mathrm{~cm}^{-1}$. ${ }^{1} \mathrm{H}$ NMR spectra were recorded in $d_{6}$ DMSO with a Bruker $300 \mathrm{MHz}$ NMR spectrometer. Mass spectra were measured on an Agilent 6224 TOF LC/MS instrument.

\section{Synthesis and xharacterization}

\section{Synthesis of complex 1}

A solution $(20 \mathrm{~mL})$ of $\mathrm{K}_{2} \mathrm{PtCl}_{4}(2.1 \mathrm{~g}, 5.0 \mathrm{mmoL})$ was added to the ligand $(1.1 \mathrm{~g}, 5.0 \mathrm{mmoL})$ in water $(5 \mathrm{~mL})$. The reaction mixture was heated to $60^{\circ} \mathrm{C}$ and stirred for 72 $\mathrm{h}$ in the dark. Plenty of yellow precipitate was filtered off, washed with water repeatedly, and then dried in vacuum.

\section{General synthesis of complexes 2-4}

To a suspending aqueous solution $(150 \mathrm{~mL})$ containing $1 \mathrm{mmoL}$ of complex 1 , silver dicarboxylate (1 $\mathrm{mmoL}$ ) was added. The reaction mixture was heated to $40^{\circ} \mathrm{C}$ and stirred for $24 \mathrm{~h}$ under the lighting shielding condition. After the mixture was cooled to the room temperature, $\mathrm{AgCl}$ deposits were filtered off and washed with water. The filtrate was concentrated to $5-10 \mathrm{~mL}$ by a rotatory evaporator and then kept cool at $4{ }^{\circ} \mathrm{C}$ for several hours. The resulting offwhite solids were filtered off, washed with a small quantity of iced water, and then dried in vacuum.

\section{Complex 1}

$\left(\mathrm{C}_{14} \mathrm{H}_{30} \mathrm{Cl}_{2} \mathrm{~N}_{2} \mathrm{Pt}\right)$ : Yield:95\%, yellow powder. Elem anal. Calcd for $\mathrm{C}_{14} \mathrm{H}_{30} \mathrm{Cl}_{2} \mathrm{~N}_{2} \mathrm{Pt}: \mathrm{C}, 34.15 ; \mathrm{H}, 6.11 ; \mathrm{N}$, 5.70. Found: C, 34.33; H, 6.36; N, 5.48. IR $\left(\mathrm{KBr}, \mathrm{cm}^{-1}\right)$ : 3444(br), 3121,2950,2863,1459, 1235,1159,505; ${ }^{1} \mathrm{H}$ NMR (d $d_{6}$-DMSO/TMS, ppm): $\delta 1.07-1.18\left(\mathrm{~m}, 12 \mathrm{H}, \mathrm{CHCH}_{3}\right)$, 1.21-1.90 (m, 8H, $\mathrm{CH}_{2}$ of DACH), 2.21-2.30 (m, $2 \mathrm{H}$, $\left.\mathrm{CHCH}_{3}\right), 2.63-2.69(\mathrm{~m}, 2 \mathrm{H}, \mathrm{NHCH}), 2.85-2.90(\mathrm{~m}, 4 \mathrm{H}$, $\left.\mathrm{NHCH}_{2}\right), 4.58(\mathrm{~m}, 2 \mathrm{H}, \mathrm{NH})$; ESI-MS: $\mathrm{m} / \mathrm{z}[\mathrm{M}+\mathrm{Cl}]=$ $526(100 \%)$.

\section{Complex 2}

$\left(\mathrm{C}_{16} \mathrm{H}_{30} \mathrm{~N}_{2} \mathrm{O}_{4} \mathrm{Pt}\right)$ : Yield: $51 \%$, white powder. Elem anal. Calcd for $\mathrm{C}_{16} \mathrm{H}_{30} \mathrm{~N}_{2} \mathrm{O}_{4} \mathrm{Pt}$ : C, 37.72; H, 5.93; N, 5.50. Found: C, 37.53; H, 5.68; N, 5.25. IR $\left(\mathrm{KBr}, \mathrm{cm}^{-1}\right)$ : 3860(br), 3147, 2955, 1675, 1462, 1396, 805; ${ }^{1} \mathrm{H}$ NMR (d $d_{6}$-DMSO/TMS, ppm): 0.90-1.06 (m, 12H, $\left.\mathrm{CH}_{3}\right), 1.33-$ $1.97\left(\mathrm{~m}, 10 \mathrm{H}, \mathrm{CH}_{2}\right.$ of DACH and $\left.\mathrm{CH}_{3} \mathrm{CH}\right), 2.11-2.21(\mathrm{~m}$, $4 \mathrm{H}, \mathrm{NHCH}_{2}$ ), 2.57 (m, 2H, NHCH), 6.50 (s, 2H, CHNH); ESI-MS: $\mathrm{m} / \mathrm{z}[\mathrm{M}+\mathrm{Na}]^{+}=532(100 \%)$.

\section{Complex 3}

$\left(\mathrm{C}_{17} \mathrm{H}_{32} \mathrm{~N}_{2} \mathrm{O}_{4} \mathrm{Pt}\right)$ : Yield: $21 \%$, white powder. Elem anal. Calcd for $\mathrm{C}_{17} \mathrm{H}_{32} \mathrm{~N}_{2} \mathrm{O}_{4} \mathrm{Pt}$ : C, 39.00; H, 6.12; N, 5.35. Found: C, 38.81; H, 6.01; N, 5.15. IR $\left(\mathrm{KBr}, \mathrm{cm}^{-1}\right)$ : 3399(br), 1579, 1355, 696; ' $\mathrm{H}$ NMR ( $d_{6}$-DMSO/TMS, ppm): 0.99-1.02 (m, 12H, $\left.\mathrm{CH}_{3}\right), 1.12-1.63(\mathrm{~m}, 10 \mathrm{H}$, $\mathrm{CH}_{2}$ of DACH and $\left.\mathrm{CH}_{3} \mathrm{CH}\right), 2.06-2.12\left(\mathrm{~m}, 4 \mathrm{H}, \mathrm{NHCH}_{2}\right)$, 2.24-2.33 (m, 2H, NHCH), 3.19 (s, $\left.2 \mathrm{H},(\mathrm{CO})_{2} \mathrm{CH}_{2}\right), 6.12$ (m, 2H, CHNH); ESI-MS: $\mathrm{m} / \mathrm{z}[\mathrm{M}+\mathrm{Na}]^{+}=546(100 \%)$.

\section{Complex 4}

$\left(\mathrm{C}_{20} \mathrm{H}_{36} \mathrm{~N}_{2} \mathrm{O}_{4} \mathrm{Pt}\right)$ : Yield: $33 \%$, white powder. Elem anal. Calcd for $\mathrm{C}_{20} \mathrm{H}_{36} \mathrm{~N}_{2} \mathrm{O}_{4} \mathrm{Pt}$ : C, 42.63; H, 6.39; N, 4.97. Found: C, 42.75; H, 6.47; N, 4.72. IR ( $\left.\mathrm{KBr}, \mathrm{cm}^{-1}\right): 3122(\mathrm{br})$, $2951,2868,1646,1463,1350,1114,515$; ${ }^{1} \mathrm{H}$ NMR (d6DMSO/TMS, ppm): 0.89-1.03 (m, 12H, CH3), 1.05-1.70 (m, $10 \mathrm{H}, \mathrm{CH} 2 \mathrm{of} \mathrm{DACH}$ and $\left.\mathrm{CH}_{3} \mathrm{CH}\right), 2.07-2.11$ (m, $2 \mathrm{H}, \mathrm{CH}_{2}$ of cyclobutyl), 2.23-2.36 (m, 4H, NHCH2), 2.612.67 (m, 2H, NHCH), 2.70-2.76 (m, 4H, $\mathrm{CH}_{2}$ of cyclobutyl), $5.85(\mathrm{~m}, 2 \mathrm{H}, N H)$; ESI-MS: $\mathrm{m} / \mathrm{z}[\mathrm{M}+\mathrm{Na}]^{+}=586(100 \%)$.

\section{Cell culture}

Human cancer cell lines HepG2, SGC-7901, HCT116, A549, NCI-H1299 and MCF-7 as well as normal liver cell line L02 were purchased from the Cell Bank of Shanghai Institute of Cell Biology. Among them, MCF-7, HepG2 cells were cultured at $37{ }^{\circ} \mathrm{C}$ in $5 \%$ $\mathrm{CO}_{2}$ with DMEM supplemented with $10 \%$ fetal bovine serum (FBS) (Hyclone, Lifescience, USA) and 1\% penicillin/streptomycin (Beyotime, Nantong, China), while HCT-116, SGC-7901, A549, NCI-H1299 and L02 cells were cultured at $37{ }^{\circ} \mathrm{C}$ in $5 \% \mathrm{CO}_{2}$ with RPMI1640 supplemented with $10 \%$ FBS and $1 \%$ penicillin/ streptomycin. Cells were passed every 2 days and restarted from frozen stocks upon reaching pass number 20. 


\section{In vitro cytotoxic activity}

In vitro cytotoxicity of the platinum compounds against human hepatocellular carcinoma (HepG-2), gastric carcinoma (SGC-7901), non-small-cell lung cancer (A549), and colorectal cancer (HCT-116) cell lines were measured by the MTT assays. Briefly, the cells were seeded in 96-well cultured plates at a density of 5000 cells/well. After overnight incubation $(16 \mathrm{~h})$, the cells were treated with the platinum complexes. After $48 \mathrm{~h}$ of incubation, $10 \mu \mathrm{L}$ of a freshly diluted 3-(4,5-dimethyl-2thiazolyl)-2,5-diphenyl-2H-tetrazolium bromide (MTT) solution $(5 \mathrm{mg} / \mathrm{mL})$ were added to each well and the plates were incubated at $37^{\circ} \mathrm{C}$ in a humidified $5 \% \mathrm{CO}_{2}$ atmosphere for $4 \mathrm{~h}$. At the end of the incubation period the medium was removed and the formazan product was dissolved in $150 \mu \mathrm{L}$ of DMSO. The cell viability was evaluated by measurement of the absorbance at $490 \mathrm{~nm}$, using an Absorbance Reader (BioRad). $\mathrm{IC}_{50}$ values (compound concentration that produces $50 \%$ of cell growth inhibition) were calculated from curves constructed by plotting cell survival inhibitory rate (\%) versus drug concentration logarithm. All experiments were repeated in three times. The reading values were converted to the percentage of control (\% cell survival). Cytotoxic effects were expressed as $\mathrm{IC}_{50}$ values.

\section{Reactions of complex 3 with DNA}

Herring sperm DNA was dissolved in $10 \mathrm{mM}$ phosphate buffer (pH 7.4) containing $10 \mathrm{mM} \mathrm{NaClO}_{4}$. The DNA concentration was determined by UV-vis spectra at $260 \mathrm{~nm}$ with an extinction coefficient of $6600 \mathrm{M}^{-1}$. The mixture of DNA with platinum complexes were incubated at $37^{\circ} \mathrm{C}$ in the dark. The fluorescence was measured in $0.4 \mathrm{M} \mathrm{NaCl}$ to avoid the second fixation site of $\mathrm{EtBr}$ to DNA. EtBr $(0.04 \mathrm{mg} / \mathrm{mL})$ was added to the $0.01 \mathrm{mg} /$ $\mathrm{mL}$ DNA solution before the fluorescence measurement. Fluorescence spectra were recorded under following conditions: scan speed $2000 \mathrm{~nm} \mathrm{~min}{ }^{-1}$; excitation slit width was $5 \mathrm{~nm}$ and emission slit width was $10 \mathrm{~nm}$. The excitation and emission wavelength was $530 \mathrm{~nm}$ and $592 \mathrm{~nm}$, respectively.

\section{Cellular platinum uptake and DNA platination assay}

The cellular uptakes of oxaliplatin, complex 3 and complex 3a were measured on A549, NCI-H1299 and L02 cells. The cells were seeded in 6-well plates overnight and then incubated with $10 \mu \mathrm{M}$ drugs at $37^{\circ} \mathrm{C}$ in standard culture conditions. After $4 \mathrm{~h}$, the cells were washed with PBS buffer ( $\mathrm{pH}$ 7.4) for three times, and harvested by trypsinization. After re-suspension in PBS, the pellet was washed with PBS and collected per centrifugation (5910R, Eppendorf) at $500 \mathrm{~g}$ for $5 \mathrm{~min}$ at $4^{\circ} \mathrm{C}$. The organelles were then isolated via differential centrifugation. All cellular compartments (mitochondria, lysosomes and nucleus) were isolated from A549 and NCI-H1299 cancer cells for direct comparative purposes. The supernatant phases discarded during the isolation of nuclei, lysosomes and mitochondria procedures were collected and formed the "residual" fraction. An aliquot of crude lysate after homogenization, nuclear, mitochondrial (pellet lysed via freeze and thaw cycles followed by 20 min incubation in ultrasonic bath), lysosomal and residual fraction was each used for protein quantification using the Bradford method [53]. The harvested cells were concentrated and digested by nitric acid for the ICP measurement. The cell numbers were counted before the digested. For the measurement of Pt concentration in cellular DNA in A549, NCI-H1299 cancer cells, DNA was isolated by applying Genomic DNA Mini Preparation Kit (Beyotime, China), and Pt content in DNA was analyzed by ICP.

\section{Apoptosis assessment}

Annexin V-FITC apoptosis detection kit (Keygen, Jiangsu, China) assay was performed according to the manufacturer's protocol. Briefly, the A549 and NCI-H1299 cancer cells were treated with oxaliplatin, complex 3, complex $3 \mathrm{a}$ of $10 \mu \mathrm{M}$ respectively for $24 \mathrm{~h}$ and washed with PBS. Then the cells were collected, resuspended in binding buffer ( $\mathrm{pH}$ 7.5, $10 \mathrm{mM}$ HEPES, $2.5 \mathrm{mM} \mathrm{CaCl}_{2}$ and $140 \mathrm{mM} \mathrm{NaCl}$ ), incubated with Annexin V-FITC and then PI for $10 \mathrm{~min}$ in the dark at room temperature, the processed cells were analyzed by flow cytometry (FACSCalibur, Becton Dickinson) and a computer station running Cell-Quest software. (BD Biosciences, Franklin Lakes, $\mathrm{NJ})$.

\section{Caspase- 3 activation analysis}

For the quantification of activation of caspase-3 in cancer cells, $5 \times 10^{5}$ cancer cells were seeded in a 60 $\mathrm{mm}$ dish and allowed to adhere for 1 day. The cells were incubated with oxaliplatin, complex 3 and complex $3 \mathrm{a}$ at a concentration of $10 \mu \mathrm{M}$ for $24 \mathrm{~h}$ to induce the activation of caspase-3. As a reference control, the cells were only incubated with fresh media at $37^{\circ} \mathrm{C}$. Then, the cells were washed with PBS to eliminate the remaining drugs and harvested using trypsin-EDTA. All the groups of cells were collected into microtubes following incubation with 300 $\mathrm{mL}$ media containing $1 \mathrm{~mL}$ of FITC-DEVD-FMK (Caspase 3 (active) FITC Staining Kit (ab65613)) for $1 \mathrm{~h}$ at $37^{\circ} \mathrm{C}$ under $5 \% \mathrm{CO}_{2}$. Subsequently, centrifugation of the cells was performed to collect cell pellets and washed 2 times with washing buffer. Each group of cells was resuspended with $300 \mathrm{~mL}$ of the washing buffer and transferred 100 $\mathrm{mL}$ per well in a microtiter plate reader. The quantification of caspase-3 was evaluated as Relative Fluorescence Unit(RFU) using Fluorophotometer (Max Gemini EM, 
SoftMax ${ }^{\circledR}$ Pro 5, Molecular Devices Corp., Sunnyvale, $\mathrm{CA}$ ) at an emission wavelength of $535 \mathrm{~nm}$ after excitation at $485 \mathrm{~nm}$. The statistical significance was evaluated with one-way ANOVA test using Graph Pad Prism 4 software.

\section{Colony formation assay}

Cells were trypsinized and plated at a density of 500 perplate. Fourteen days later, $50 \mu \mathrm{M}$ oxaliplatin, complex 3 and complex $3 \mathrm{a}$ in cell culture medium were added to the plates, and cells were incubated for a further 7 days. Cells were then fixed with $3 \%$ paraformaldehyde, stained with crystal violet and imaged with a light microscope. The experiment was performed in triplicate. The number of colonies, defined as containing $>50$ cells, was counted.

\section{Cell-cycle analysis}

Cell cycle was analyzed by flow cytometry as described previously [54]. Data were analyzed with FlowJo software (TreeStar, Inc.).

\section{Mitochondrial transmembrane potential $(\Delta \Psi \mathrm{m})$ assessment}

The electrical potential difference across inner mitochondrial membrane ( $\Delta \Psi \mathrm{m})$ was monitored using the $\Delta \Psi \mathrm{m}$-specific fluorescent probe JC-1 (Molecular Probes Inc., Eugene, OR), a sensitive fluorescent dye. In brief, the A549 and NCI-H1299 cancer cells treated with $10 \mu \mathrm{M}$ of oxaliplatin, complex 3 and complex $3 \mathrm{a}$ for $24 \mathrm{~h}$ were harvested with ice-cold PBS and resuspended in RPMI1640 medium at a density of $0.5 \times 10^{6}$ cells $/ \mathrm{ml}$, then the cells were permeabilized with $0.3 \%$ Triton X-100, washed with ice-cold PBS, incubated with $10 \mu \mathrm{M} \mathrm{JC}-1$ for $15 \mathrm{~min}$ at $37^{\circ} \mathrm{C}$ in the dark and observed under a fluorescence microscope (Olympus IX51, Japan). Red fluorescence is attributable to a potential-dependent aggregation in the mitochondria. Green fluorescence, reflecting the monomeric form of JC-1, appeared in the cytosol after mitochondrial membrane depolarization. Relative fluorescence intensities were monitored using the flow cytometry (FACSCalibur, Becton Dickinson), and analyzed by the software Modfit and Cell Quest (BD Biosciences, Franklin Lakes, NJ) with settings of FL1 (green) at $530 \mathrm{~nm}$ and FL2 (red) at $585 \mathrm{~nm}$.

\section{Measurement of ATP production}

The ATP production assay kit (Haimen, Jiangsu, China) was used to measure intracellular ATP level according to the manufacturer's instructions. In brief, cells were treated with $10 \mu \mathrm{M}$ oxaliplatin, complex 3 and complex $3 \mathrm{a}$ for $12 \mathrm{~h}$, then incubated with $100 \mu \mathrm{L}$ Nuclear Releasing Reagent for $5 \mathrm{~min}$ at $37^{\circ} \mathrm{C}$ with gentle shaking, followed by further incubation with $1 \mu \mathrm{L}$ ATP monitoring enzyme. Detection was performed using the luminometer Orion II (Berthold DS, Bleichstr, Pforzheim, Germany).

\section{ROS measurement}

The generation of ROS induced by complex 3 was determined with the cell permeant fluorogenic probe 2',7'-dichlorodihydrofluorescein diacetate ( $\mathrm{H}_{2} \mathrm{DCFDA}$; Molecular Probes, Invitrogen, Darmstadt, Germany) as described [55]. $\mathrm{H}_{2}$ DCFDA diffuses into the cell, where it is enzymatically converted by intracellular esterases and oxidized into the high fluorescence compound DCF, which allows the determination of $\mathrm{H}_{2} \mathrm{O}_{2}$, peroxynitrite anions and peroxyl radicals. Approximately $4 \times 10^{3}$ A549 and NCI-H1299 cancer cells per well were plated on white bottom 96-well plates in extracellular fluid $(140 \mathrm{nM} \mathrm{NaCl}$, $3 \mathrm{mM} \mathrm{KCl}, 1 \mathrm{mM} \mathrm{CaCl}, 1 \mathrm{mM} \mathrm{MgCl}, 10 \mathrm{mM}$ HEPES and $25 \mathrm{mM}$ glucose; $\mathrm{pH}$ 7.4). After $24 \mathrm{~h}$ incubation, cells were treated with $10 \mu \mathrm{M}$ oxaliplatin, complex 3 and complex $3 \mathrm{a}$ for $6 \mathrm{~h}$ at $37^{\circ} \mathrm{C}$. Then, cells were loaded with $10 \mathrm{mM} \mathrm{H}_{2} \mathrm{DCFDA}$ for $30 \mathrm{~min}$ at $37^{\circ} \mathrm{C}$ and $5 \% \mathrm{CO}_{2}$. Then, cells DCF generation was measured over time using a fluorometer (Fluostar BMG Labtech, Offenburg, Germany) at $492 \mathrm{~nm}$ excitation and $520 \mathrm{~nm}$ emission.

\section{$\mathrm{H}_{2} \mathrm{O}_{2}$ measurement}

The production of $\mathrm{H}_{2} \mathrm{O}_{2}$ was determined with the Amplex ${ }^{\circledR}$ Red reagent (10-acetyl-3,7dihydroxyphenoxazine; Molecular Probes). In the presence of horseradish peroxidase (HPR), the Amplex ${ }^{\circledR}$ Red reagent reacts in a 1:1 stoichiometry to produce the red-fluorescent oxidation product, resorufin. Consequently, resorufin generation allows the detection of the $\mathrm{H}_{2} \mathrm{O}_{2}$ released from biological compounds. Approximately $4 \times 10^{3}$ A549 and NCI-H1299 cancer cells were plated on black bottom 96 -well plates in $120 \mathrm{ml}$ of working solution containing $40 \mathrm{mM}$ Amplex ${ }^{\circledR}$ Red reagent and $0.1 \mathrm{U} / \mathrm{ml}$ HPR, and incubated in the presence of $10 \mu \mathrm{M}$ oxaliplatin, complex 3 and complex $3 \mathrm{a}$ for $2 \mathrm{~h}$ at $37^{\circ} \mathrm{C}$. Resorufin generation was measured over time using a fluorometer (Fluostar BMG Labtech) at $544 \mathrm{~nm}$ excitation and $590 \mathrm{~nm}$ emission.

\section{Intracellular GSH measurement}

A549 and NCI-H1299 cancer cells in $6 \mathrm{~cm}$ culture plates were treated as follows: $10 \mu \mathrm{M}$ oxaliplatin, complex 3 and complex $3 \mathrm{a}$. After $4 \mathrm{~h}$, medium was removed and dishes were rinsed three times with cold PBS. The cells were harvested and cell numbers were counted. Then, intracellular GSH levels were measured using a GSH test kit (KeyGen KGT006). A549 and NCI-H1299 cancer cells without treatment were used as control groups.

\section{Gel electrophoresis}

DNA cleavage produced by oxaliplatin, complex 3 and complex $3 a$ was investigated by agarose gel electrophoresis. pET28a plasmid DNA (50 ng/mL) was 
used as the target. Appropriate dilutions of tested complexes were made, and the required volumes of solutions were added to achieve a set of concentrations in the range of 0-100 mm; pET22b DNA ( $5 \mathrm{~mL}, 0.20 \mathrm{mg}$ ) was added to each tube, and the mixtures of platinum complexes and pET22b plasmid DNA were then incubated at $37^{\circ} \mathrm{C}$ for 6 or $24 \mathrm{~h}$. Afterward, the agarose gel (made up to $1 \% \mathrm{w} / \mathrm{v}$ ) containing ethidium bromide was prepared with TA buffer (50 mm Tris-acetate, $\mathrm{pH}$ 7.5). The mixtures with loading buffer $(1 \mathrm{~mL})$ underwent electrophores is in agarose gel in TA buffer at $100 \mathrm{~V}$ for $60 \mathrm{~min}$. Bands were imaged using a Molecular Imager (Bio-Rad, USA) under UV light.

\section{Comet assay}

After the same treatment of oxaliplatin,complex 3 and complex $3 \mathrm{a}$ at $10 \mu \mathrm{M}$ for $24 \mathrm{~h}$, A549 cells $\left(1 \times 10^{5}\right.$ cells) were combined with molten LMAgarose (Trevigen) at a ratio of 1:10 (v/v) and were immediately pipetted onto CometSlide (Trevigen). Slides were incubated at $4{ }^{\circ} \mathrm{C}$ in the dark for 10 minutes, then immersed in prechilled Lysis Buffer and incubated at $4^{\circ} \mathrm{C}$ for $30 \mathrm{~min}$. Slides were immersed in Alkaline Unwinding Solution, $\mathrm{pH}>13$ (200 $\mathrm{mmol} / \mathrm{L} \mathrm{NaOH}, 1 \mathrm{mmol} / \mathrm{L} \mathrm{EDTA}$ ) for $20 \mathrm{~min}$ at room temperature in the dark. Electrophoresis was done at 21 $\mathrm{V}$ for 30 minutes using Alkaline Electrophoresis solution (200 mmol/L NaOH, $1 \mathrm{mmol} / \mathrm{L}$ EDTA). The slides were washed twice in water for 5 minutes and once in $70 \%$ EtOH for $5 \mathrm{~min}$, then dried overnight and visualized by microscopy. Under these conditions the formation of "comet tail" is indicative of SSBs, DBSs, and/or active excision repair of DNA cross-links.

\section{Analysis of SSB repair}

SSB were detected by exposing cancer cells to 10 $\mu \mathrm{M}$ oxaliplatin, complex 3 and complex $3 \mathrm{a}$, respectively, for $15 \mathrm{~min}, 30 \mathrm{~min}$ and $60 \mathrm{~min}$ in RPMI 1640 medium at $37^{\circ} \mathrm{C}$. Then the cells were washed three times with PBSCMF (140 mM NaCl, $3 \mathrm{mM} \mathrm{KCl,} 8 \mathrm{mM} \mathrm{Na}_{2} \mathrm{HPO}_{4}$ and $1 \mathrm{mM} \mathrm{KH}_{2} \mathrm{PO}_{4}$ ). The numbers of SSBs were determined by an alkaline elution assay as previously described [56]. The numbers of SSB in untreated cancer cells were subtracted in all cases.

\section{Nuclear $\gamma \mathrm{H} 2 \mathrm{AX}$ foci analysis}

For assessment of DSBs repair kinetics we detected the total nuclear volume for an average of 50-60 nuclei per time points and cell type. Briefly, A549 cells were grown to confluence in $35 \mathrm{~mm}$ petri-dishes with 0.17 $\mathrm{mm}$ glass bottom. After treatment of cisplatin, oxaliplatin and 3 at $50 \mu \mathrm{M}$ for $8 \mathrm{~h}$ and $12 \mathrm{~h}$, cells were fixed in $4 \%$ paraformaldehyde / PBS for $10 \mathrm{~min}$ at room temperature and incubated in nuclear extraction buffer (10 mM PIPES $\mathrm{pH}$ 6.8, $100 \mathrm{mM} \mathrm{NaCl}, 300 \mathrm{mM}$ sucrose, $3 \mathrm{mM} \mathrm{MgCl}_{2}$,
$1 \mathrm{mM}$ EGTA, $0.5 \%$ Triton X-100) at $55 \mathrm{rpm}$ on a rotating shaker for $15 \mathrm{~min}$. Non-specific binding was blocked by incubation with 5\% FCS/PBS/0.1\% Triton X-100 for $1 \mathrm{~h}$ at RT. Immunostaining for MDC1 (1:400), and XRCC1 $(1: 1000)$ was followed by detection with species specific secondary AlexaFluor conjugates (1:1000; Invitrogen, Carlsbad, USA). Numbers of $\gamma \mathrm{H} 2 \mathrm{AX}$ foci were counted in 50-60 nuclei and plotted over time as previously described [57].

\section{Western blot analysis}

After the treatment of the indicated concentration of $10 \mu \mathrm{M}$ oxaliplatin, complex 3 and complex $3 \mathrm{a}$ for 24 h, A549 and NCI-H1299 cancer cells were collected and lysed in lysis buffer (100 mM Tris-Cl, pH 6.8, 4\% $(\mathrm{m} / \mathrm{v})$ sodium dodecylsulfonate, $20 \%$ (v/v) glycerol, 200 $\mathrm{mM} \beta$-mercaptoethanol, $1 \mathrm{mM}$ phenylmethylsulfonyl fluoride, and $1 \mathrm{~g} / \mathrm{ml}$ aprotinin). Lysates were centrifuged at $12,000 \mathrm{~g}$ for $0.5 \mathrm{~h}$ at $4^{\circ} \mathrm{C}$. The concentrations of total proteins were measured using the BCA assay method with Varioskan spectrofluorometer and spectrophotometer (Thermo, Waltham, MA) at $562 \mathrm{~nm}$. Protein (20-100 $\mu \mathrm{g})$ prepared from the indicated cells was loaded per lane and electrophoresed in $8 \%$ or $10 \%$ sodium dodecyl sulfate polyacrylamide gel electrophoresis (SDS-PAGE), and then transferred onto polyvinylidene difluoride (PVDF) Immobilon-P membrane (Bio-Rad, USA) using a transblot apparatus (Bio-Rad, USA). The membranes were blocked with $5 \%(\mathrm{w} / \mathrm{v})$ non-fat milk at $0.5 \mathrm{~h}$ at $37^{\circ} \mathrm{C}$, followed by overnight incubation at $4^{\circ} \mathrm{C}$ with primary antibodies diluted in PBST. After washing with PBST, the membranes were incubated for $1 \mathrm{~h}$ with an IRDye' 800 conjugated secondary antibody diluted 1:20000 in PBST, and the labeled proteins were detected with an Odyssey Scanning System (Li-COR., Lincoln, Nebraska, USA).

\section{Detection of acidic vesicular organelles (AVOs)}

Flow cytometry with acridine orange staining as described in a previous study was used to detect and quantify the AVOs, one of the characteristicsof autophagy [58]. At the end of individual experiments, A549 cells were collected in phenol red-free RPMI 1640 medium. Green (FL-1) and red (FL-3) fluorescences of acridine orange were measured using a flow cytometer and CellQuest software (Becton Dickinson, San Jose, CA). The sum of the upper-left and upper-right quadrants of the cytogram was used to estimate the percentage of cells undergoing autophagy.

\section{Quantification of apoptotic and necrotic cells}

The mode of cell death was analyzed by flow cytometry with annexin V/propidium iodide (PI) double-staining to detect membrane events according 
to a previous study [59]. After individual treatments, whole cells were collected in 4-(2-hydroxyethyl)-1piperazineethanesulfonic acid (HEPES) buffer containing $10 \mathrm{mM}$ HEPES (pH 7.4), $140 \mathrm{mM} \mathrm{NaCl}$, and $2.5 \mathrm{mM}$ $\mathrm{CaCl}_{2}$. Cells were subsequently stained with annexin $\mathrm{V}(2.5 \mu \mathrm{g} / \mathrm{ml})$ and PI $(2 \mathrm{ng} / \mathrm{ml})$ for $20 \mathrm{~min}$, followed by analysis by flow cytometry (Beckman Coulter). Cystograms of the four quadrants in the figure were used to distinguish normal (annexin $\mathrm{V}^{-} / \mathrm{PI}^{-}$), early apoptotic (annexin $\mathrm{V}^{+} / \mathrm{PI}^{-}$), late apoptotic(annexin $\mathrm{V}^{+} / \mathrm{PI}^{+}$), and necrotic cells (annexin $\mathrm{V}^{-} / \mathrm{PI}^{+}$). The sum of early apoptosis and late apoptosis is presented as total apoptosis.

\section{In vivo antitumor efficacy of complex 3}

Thirty-five nude mice (BALB/c) with body weight range from 18-22 g, were supplied by Shanghai Laboratory Animal Center, China Academy of Sciences. Experimental protocols were in accordance with National Institutes of Health regulations and approved by the Institutional Animal Care and Use Committee. All animals were randomly divided into 5 groups. The A549 single-cell suspension in PBS $\left(1 \times 10^{7}\right.$ cells per mouse) was injected subcutaneously into the right oxter of nude mice. When tumor grew to a size of $80-150 \mathrm{~mm}^{3}$ at 12 days, the mice were administrated via oxaliplatin (dosed intravenously at $5 \mathrm{mg} / \mathrm{kg}$ twice a week), complex 3 (dosed intravenously at $5 \mathrm{mg} / \mathrm{kg}$ once every three days), complex $3 \mathrm{a}$ (dosed intravenously at $5 \mathrm{mg} / \mathrm{kg}$ once every three days). The control group was administered glucose. The tumor growth was monitored by measuring the perpendicular diameter of the tumor using calipers every two days and calculated according to the formula:

Tumor volume $\left(\mathrm{mm}^{3}\right)=0.5 \times$ length $\times$ width $^{2}$

Growth curves were plotted using the average tumor volume within each experimental group at the set time points. The whole group of mice was sacrificed after the last treatment, then tumor weight was evaluated as the antitumor activity of the corresponding groups, and the kidneys, livers and tumors were excised for immunohistochemistry analysis. The body weight and physical state of the mice were measured simultaneously as an indicator of systemic toxicity.

\section{Blood stability test of complex 3 with rat plasma}

To a volume of $0.6 \mathrm{~mL}$ rat plasma was added $10 \mu \mathrm{L}$ of a DMSO solution of oxaliplatin and complex $3(10 \mathrm{mM})$, resulting in a final concentration of $50 \mu \mathrm{M}$. At varying time points $(0,2,4$ and $8 \mathrm{~h})$ at $37^{\circ} \mathrm{C}$, a $300 \mu \mathrm{L}$ aliquot was removed from the incubating blood. The ICPMS measurement was served to confirm the blood stability of complex 3 in rat plasma.

\section{Pharmacokinetics studies}

Twenty-four SD rats (240-250 g) were supplied by Shanghai Laboratory Animal Center, China Academy of
Sciences. Experimental protocols were in accordance with National Institutes of Health regulations and approved by the Institutional Animal Care and Use Committee. SD rats composed of half male and half female were randomly divided into 2 groups: 1) oxaliplatin (5 mg/ $\mathrm{kg}$ ); 2) complex 3 (an equivalent dose to $5 \mathrm{mg}$ oxaliplatin/ $\mathrm{kg}$ ). $0.6 \mathrm{ml}$ of blood compounds were collected from orbital cavity at $5 \mathrm{~min}$ followed by $0.5,1,2,4,8,12$ and $24 \mathrm{~h}$ after intravenous administration, heparinized and then centrifuged at $4000 \mathrm{rpm}$ for $20 \mathrm{~min}$ at $4^{\circ} \mathrm{C}$. The supernatant plasma was collected for measurement of $\mathrm{Pt}$ content using ICP-MS. The apparent plasma half-life time was calculated using a Phoenix Win Nonlin 6.3 Program (Pharsight Cooperation, St. Louis Missouri, USA).

\section{Statistical analysis}

All data in different experimental groups were expressed as mean \pm SEM. These data shown in the study were obtained in at least three independent experiments. Statistical analyses were performed using an unpaired, two-tailed Student's $t$-test. All comparisons are made relative to untreated controls and significance of difference is indicated as $* P<0.05$ and $* * P<0.01$.

\section{ACKNOWLEDGMENTS}

We are grateful to the National Natural Science Foundation of China (Grant No. 21271041 and 81503099) and the New Drug Creation Project of the National Science and Technology Major Foundation of China (Grant No. 2013ZX09402-102-006) for financial aids to this work. The research was also supported by Jiangsu Province Natural Science Foundation (Grant No. BK20150643). The authors would also like to thank the Fundamental Research Funds for the Central Universities (Project 2242013K30011) for supplying basic facilities to our key laboratory. We also want to express our gratitude to the Priority Academic Program Development of Jiangsu Higher Education Institutions for the construction of fundamental facilities (Project 1107047002).

\section{CONFLICTS OF INTEREST}

The authors declare that they have no competing interests.

\section{REFERENCES}

1. Rosenberg B, VanCamp L, Trosko JE, Mansour, VH. Platinum compounds: a new class of potent anti-tumor agents. Nature. 1969; 222:385-386.

2. Kelland L. The resurgence of platinum-based cancer chemotherapy. Nat Rev Cancer. 2007; 7:573-584. 
3. Wang XY, Wang XH, Guo ZJ. Functionalization of platinum complexes for biomedical applications. Acc Chem Res. 2015; 48:2622-2631.

4. Liu FF, Gou SH, Chen FH, Fang L, Zhao J. Study on antitumor platinum(II) complexes of chiral diamines with dicyclic species as steric hindrance. J Med Chem. 2015; 58:6368-6377.

5. Graf N, Lippard SJ. Redox activation of metalbased prodrugs as a strategy for drug delivery. Adv Drug Delivery Rev. 2012; 64:993-1004.

6. Wilson JJ, Lippard SJ. In vitro anticancer activity of cisdiammineplatinum(II) complexes with $\beta$-diketonate leaving group ligands. J Med Chem. 2012; 55:5326-5336.

7. Fuertes MA, Alonso C, Perez JM. Biochemical modulation of cisplatin mechanisms of action: enhancement of antitumor activity and circumvention of drug resistance. Chem Rev. 2003; 103:645-662.

8. Zhang W, Shen JL, Su H, Mu G, Sun JH, Tan CP, Liang XJ, Ji LN, Mao ZW. Co-delivery of cisplatin prodrug and chlorin e6 by mesoporous silica nanoparticles for chemophotodynamic combination therapy to combat drug resistance. ACS Appl Mater Interfaces. 2016; 8:13332-13340.

9. Galanski M, Jakupec MA, Keppler BK. Update of the preclinical situation of anticancer platinum complexes: Novel design strategies and innovative analytical approaches. Curr Med Chem. 2005; 12:2075-2094.

10. Mukherjea D, Rybak LP, Sheehan KE, Kaur T, Ramkumar V, Jajoo S, Sheth S. The design and screening of drugs to prevent acquired sensorineural hearing loss. Expert Opin Drug Discovery. 2011; 6:491-505.

11. Wang D, Lippard SJ. Cellular processing of platinum anticancer drugs. Nat Rev Drug Discovery. 2005; 4:307-320.

12. Yu CW, Li KK, Pang SK, Au-Yeung SC, Ho YP. Anticancer activity of a series of platinum complexes integrating demethylcantharidin with isomers of 1,2-diaminocyclohexane. Bioorg Med Chem Lett. 2006; 16:1686-1691.

13. Liu $\mathrm{X}$, Shen $\mathrm{H}$, Zhu HB, Cui $\mathrm{K}$, Gou SH. In vitro cytotoxicity study on platinum (II) complexes with epoxysuccinates as leaving groups. Bioorg Med Chem Lett. 2007; 17:3831-3834.

14. Sun YY, Yin RT, Gou SH, Zhao J. Antitumor platinum(II) complexes of N-monoalkyl-1R, 2R-diaminocyclohexane derivatives with alkyl groups as hindrance. J Inorg Biochem. 2012; 112:68-76.

15. Yu Y, Lou LG, Liu WP, Zhu HJ, Ye QS, Chen XZ, Gao WG, Hou SQ. Synthesis and anticancer activity of lipophilic platinum(II) complexes of 3,5-diisopropylsalicylate. Eur J Med Chem. 2008; 43:1438-1443.

16. Habala L, Galanski M, Yasemi A, Nazarov AA, Keyserlingk NG, Keppler BK. Synthesis and structure-activity relationships of mono- and dialkyl-substituted oxaliplatin derivatives. Eur J Med Chem. 2005; 40:1149-1155.

17. Rothenburger C, Galanski M, Arion VB, Görls $H$, Weigand W, Keppler BK. Synthesis and characterization of $\quad[(1 \mathrm{R}, 2 \mathrm{R})$-trans-diaminocyclohexane $]$ platinum(II) coordinated to sulfur and selenium amino acids. Eur J Inorg Chem. 2006; 18:3746-3752.

18. Abramkin SA, Jungwirth U, Valiahdi SM, Dworak C, Habala L, Meelich K, Berger W, Jakupec MA, Hartinger CG, Nazarov AA, Galanski M, Keppler BK. \{(1R,2R,4R)4-methyl-1,2-cyclohexanediamine oxalatoplatinum(II): A novel enantiomerically pure oxaliplatin derivative showing improved anticancer activity in vivo. J Med Chem. 2010; 53:7356-7364.

19. Sun YY, Gou SH, Liu F, Yin RT, Fang L. Synthesis in vitro cytotoxicity, and interaction with DNA of platinum(II) complexes with N-monocycloalkyl derivatives of 1R,2Rdiaminocyclohexane as carrier ligands. Chem Med Chem. 2012; 7:642-649.

20. Sun YY, Liu F, Gou SH, Cheng L, Fang L, Yin RT. Synthesis and in vitro antiproliferative activity of platinum(II) complexes with N-monoalkyl 1R,2R-diaminocyclohexane as ligands. Eur J Med Chem. 2012; 55:297-306.

21. Fang L, Gou SH, Zhao J, Sun YY, Cheng L. Platinum(II) complexes with N-monoalkyl 1R,2R-diaminocyclohexane derivatives as carrier ligands and 3-hydroxycyclobutane1,1-dicarboxylate as a leaving group: Potent cytotoxicity and DNA binding ability. Eur J Med Chem. 2013; 69:842-847.

22. Zhang HY, Gou SH, Zhao J, Chen FH, Xu G, Liu X. Cytotoxicity profile of novel sterically hindered platinum(II) complexes with (1R,2R)-N1,N2-dibutyl-1,2diaminocyclohexane. Eur J Med Chem. 2015; 96:187-195.

23. Jain MV, Paczulla AM, Klonisch T, Dimgba FN, Rao SB, Roberg K, Schweizer F, Lengerke C, Davoodpour P, Palicharla VR, Maddika S, Los M. Interconnections between apoptotic, autophagic and necrotic pathways: implications for cancer therapy development. J. Cell. Mol. Med. 2013; 17:12-29.

24. Yoshimori T. Autophagy: a regulated bulk degradation process inside cells. Biochem. Biophys. Res. Commun. 2004; 313:453-458.

25. Morselli E, Galluzzi L, Kepp O, Criollo A, Maiuri MC, Tavernarakis N, Madeo F, Kroemer G. Autophagy mediates pharmacological lifespan extension by spermidine and resveratrol. Aging (Albany NY). 2009; 1:961-970. doi: 10.18632/aging.100110.

26. Kondo Y, Kanzawa T, Sawaya R, Kondo S. The role of autophagy in cancer development and response to therapy. Nat Rev Cancer. 2010; 5:726-734.

27. Mehrpour M, Esclatine A, Beau I, Codogno P. Overview of macroautophagy regulation in mammalian cells. Cell Res. 2010; 20:748-762.

28. Codogno P, Mehrpour M, Proikas-Cezanne T. Canonical and non-canonical autophagy: variations on a common theme of self-eating? Nat Rev Mol Cell Biol. 2011; 13:7-12.

29. Becherel OJ, Jakob B, Cherry AL, Gueven N, Fusser M, Kijas AW, Peng C, Katyal S, McKinnon PJ, Chen J, Epe B, Smerdon SJ, Taucher-Scholz G, et al. CK2 phosphorylation-dependent interaction between aprataxin and MDC1 in the DNA damage response. Nucleic Acids Res.2010; 38:1489-1503. 
30. Cotter TG. Apoptosis and cancer: the genesis of a research field. Nat Rev Cancer. 2009; 9:501-507.

31. Kohanski M, Dwyer D, Hayete B, Lawrence C, Collins J. A common mechanism of cellular death induced by bactericidal antibiotics. Cell. 2007; 130:797-810.

32. Circu M, Aw T. Reactive oxygen species, cellular redox systems, and apoptosis. Free Radic Biol Med. 2010; 48:749-762.

33. You Q, Li Z, Huang C, Yang Q, Wang X, Guo Q, Chen X, He X, Li T, Chern J. Discovery of a novel series of quinolone and naphthyridine derivatives as potential topoisomerase I inhibitors by scaffold modification. J Med Chem. 2009; 52:5649-61.

34. Foti J, Devadoss B, Winkler J, Collins J, Walker G. Oxidation of the guanine nucleotide pool underlies cell death by bactericidal antibiotics. Science. 2012; 336:315-319.

35. Kalghatgi S, Spina C, Costello J, Liesa M, Morones-Ramirez J, Slomovic S, Molina A, Shirihai O, Collins J. Bactericidal antibiotics induce mitochondrial dysfunction and oxidative damage in Mammalian cells. Sci Transl Med.2013; 5:192-195.

36. Pattingre S, Espert L, Biard-Piechaczyk M, Codogno P. Regulation of macroautophagy by mTOR and Beclin 1 complexes. Biochimie. 2008; 90:313-323.

37. Hay N, Sonenberg N. Upstream and downstream of mTOR. Genes Dev. 2004; 18:1926-1945.

38. Jones R.G. The roles, mechanisms, and controversies of autophagy in mammalian biology. Biol Reprod. 2009; 1:68.

39. Baehrecke EH. Autophagic programmed cell death in Drosophila. Cell Death Differ. 2003; 10:940-945.

40. Jain MV, Paczulla AM, Klonisch T, Dimgba FN, Rao SB, Roberg K, Schweizer F, Lengerke, C, Davoodpour P, Palicharla VR, Maddika S, Łos M. Interconnections between apoptotic, autophagic and necrotic pathways: implications for cancer therapy development. J Cell Mol Med. 2013; 17:12-29

41. Lin CJ, Chen TH, Yang LY, Shih CM. Resveratrol protects astrocytes against traumatic brain injury through inhibiting apoptotic and autophagic cell death. Cell Death Dis. 2014; 5:e1147.

42. Gupta A, Roy S, Lazar AJ, Wang WL, McAuliffe JC, Reynoso D, McMahon J, Taguchi T, Floris G, DebiecRychter M, Schoffski P, Trent JA, Debnath J, et al. Autophagy inhibition and antimalarials promote cell death in gastrointestinal stromal tumor (GIST). Proc Natl Acad Sci USA. 2010; 107:14333-14338.

43. Zhang HQ, He B, Fang N, Fang N, Lu S, Liao YQ, Wan YY, Autophagy inhibition sensitizes cisplatin cytotoxicity in human gastric cancer cell line SGC7901. Asian Pac. J Cancer Prev. 2013; 14:4685-4688.

44. Jones RG. The roles, mechanisms, and controversies of autophagy in mammalian biology. Biol Reprod. 2009; 1:68.

45. Pattingre S, Espert L, Biard-Piechaczyk M, Codogno P. Regulation of macroautophagy by $\mathrm{mTOR}$ and Beclin 1 complexes. Biochimie. 2008; 90:313-323.
46. Suzuki K, Gerelchuluun A, Hong Z, Sun L, Zenkoh J, Moritake T, Tsuboi K. Celecoxib enhances radiosensitivity of hypoxic glioblastoma cells through endoplasmic reticulum stress. Neuro-Oncology. 2013; 15:1186-1199.

47. Chen N, Karantza-Wadsworth V. Role and regulation of autophagy in cancer. Biochim. Biophys. Acta. 2009; 1793:1516-1523.

48. Feng Z, Zhang H, Levine AJ, Jin S. The coordinate regulation of the p53 and mTOR pathways in cells. Proc. Natl Acad. Sci USA. 2005; 102:8204-8209.

49. Kim EH, Deng CX, Sporn MB, Liby KT. CDDOimidazolide induces DNA damage, G2/M arrest and apoptosis in BRCA1-mutated breast cancer cells. Cancer Prev. Res. 2011; 4:425-434.

50. Gao M, Yeh PY, Lu YS, Hsu CH, Chen KF, Lee WC, Feng WC, Chen CS, Kuo ML, Cheng AL. OSU-03012, a novel celecoxib derivative, induces reactive oxygen speciesrelated autophagy in hepatocellular carcinoma. Cancer Res. 2008; 68:9348-9357.

51. Duan W, Jin X, Li Q, Tashiro S, Onodera S, Ikejima T. Silibinin induced autophagic and apoptotic cell death in HT1080 cells through a reactive oxygen species pathway. J Pharmacol Sci. 2010; 113:48-56.

52. Montero J, Dutta C, van Bodegom D, Weinstock D, Letai A. p53 regulates a nonapoptotic death induced by ROS. Cell Death Differ. 2013; 20:1465-1474.

53. Hipfner DR, Deeley RG, Cole SP. Structural, mechanistic and clinical aspects of MRP1. Biochim Biophys Acta.1999; 1461:359-76.

54. Ang WH, Khalaila I, Allardyce CS, Juillerat-Jeanneret L, Dyson PJ. Rational design of platinum (IV) compounds to overcome glutathione-S-transferase mediated drug resistance. J Am Chem Soc. 2005; 127:1382-1383.

55. Chen FH, Zhang LB, Qiang L, Yang Z, Wu T, Zou MJ, Tao L, You QD, Li ZY, Yang Y, Guo QL. Reactive oxygen species-mitochondria pathway involved in LYG-202induced apoptosis in human hepatocellular carcinoma HepG2 cells. Cancer Lett. 2010; 296:96-105.

56. O’Grady S, Finn SP, Cuffe S, Richard DJ, O'Byrne KJ, Barr MP. The role of DNA repair pathways in cisplatin resistant lung cancer. Cancer Treat. Rev. 2014; 40:1161-1170.

57. Jiang H, Yang LY. Cell Cycle Checkpoint Abrogator UCN01 inhibits DNA repair association with attenuation of the interaction of XPA and ERCC1 nucleotide excision repair proteins, Cancer. Res. 1999; 59:4529-4534.

58. Kanzawa T, Bedwell J, Kondo Y, Kondo S, Germano IM. Inhibition of DNA repair for sensitizing resistant glioma cells to temozolomide. J. Neurosurg. 2003; 99:1047-1052.

59. Lin CJ, Lee CC, Shih YL, Lin TY, Wang SH, Lin YF, Shih CM. Resveratrol enhances the therapeutic effect of temozolomide against malignant glioma in vitro and in vivo by inhibiting autophagy. Free Radic. Biol. Med. 2012; 52:377-391. 